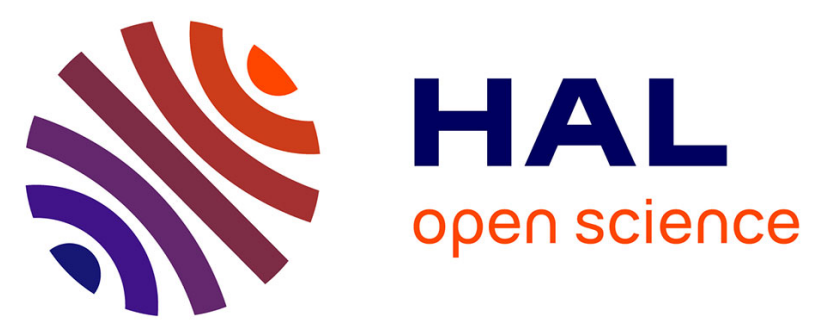

\title{
Crustal structure and evolution of the Pyrenean-Cantabrian belt: A review and new interpretations from recent concepts and data
}

A. Teixell, P. Labaume, P. Ayarza, N. Espurt, Michel de Saint Blanquat, Yves Lagabrielle

\section{To cite this version:}

A. Teixell, P. Labaume, P. Ayarza, N. Espurt, Michel de Saint Blanquat, et al.. Crustal structure and evolution of the Pyrenean-Cantabrian belt: A review and new interpretations from recent concepts and data. Tectonophysics, 2018, 724-725, pp.146-170. 10.1016/j.tecto.2018.01.009 . insu-01683989

\section{HAL Id: insu-01683989 \\ https://hal-insu.archives-ouvertes.fr/insu-01683989}

Submitted on 15 Jan 2018

HAL is a multi-disciplinary open access archive for the deposit and dissemination of scientific research documents, whether they are published or not. The documents may come from teaching and research institutions in France or abroad, or from public or private research centers.
L'archive ouverte pluridisciplinaire HAL, est destinée au dépôt et à la diffusion de documents scientifiques de niveau recherche, publiés ou non, émanant des établissements d'enseignement et de recherche français ou étrangers, des laboratoires publics ou privés. 


\section{Accepted Manuscript}

TEGTONOPHYSICS

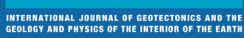

Crustal structure and evolution of the Pyrenean-Cantabrian belt: A review and new interpretations from recent concepts and data

A. Teixell, P. Labaume, P. Ayarza, N. Espurt, M. de Saint Blanquat, Y. Lagabrielle

PII:

S0040-1951(18)30020-9

DOI: https://doi.org/10.1016/j.tecto.2018.01.009

Reference: TECTO 127747

To appear in: Tectonophysics

Received date: 20 July 2017

Revised date: 19 December 2017

Accepted date: 4 January 2018

Please cite this article as: A. Teixell, P. Labaume, P. Ayarza, N. Espurt, M. de Saint Blanquat, Y. Lagabrielle, Crustal structure and evolution of the Pyrenean-Cantabrian belt: A review and new interpretations from recent concepts and data. The address for the corresponding author was captured as affiliation for all authors. Please check if appropriate. Tecto(2017), https://doi.org/10.1016/j.tecto.2018.01.009

This is a PDF file of an unedited manuscript that has been accepted for publication. As a service to our customers we are providing this early version of the manuscript. The manuscript will undergo copyediting, typesetting, and review of the resulting proof before it is published in its final form. Please note that during the production process errors may be discovered which could affect the content, and all legal disclaimers that apply to the journal pertain. 
Crustal structure and evolution of the Pyrenean-Cantabrian belt: a review and new interpretations from recent concepts and data

A. Teixell, P. Labaume, P. Ayarza, N. Espurt, M. de Saint Blanquat, Y. Lagabrielle

${ }^{1}$ Dept. de Geologia, Universitat Autònoma de Barcelona, 08193 Bellaterra, Spain (antonio.teixell@uab.es, +34 935811163)

${ }^{2}$ Géosciences Montpellier, Université de Montpellier-CNRS, 34095 Montpellier, France (pierre.labaume@gm.univ-montp2.fr)

32Depto. de Geología, Universidad de Salamanca, 3700 Salamanca, Spain (puy@usal.es)

${ }^{4}$ Aix-Marseille Univ., CNRS, IRD, Coll de France, CEREGE, Aix en Provence, France (espurt@cerege.fr)

${ }^{5}$ Géosciences Environnement Toulouse / Observatoire Midi-Pyrénées-CNRS, 31400 Toulouse, France (michel.desaintblanquat@get.obs-mip.fr)

${ }^{6}$ Géosciences Rennes, Université de Rennes 1-CNRS, 35042 Rennes, France (yveslagabrielle@yahoo.fr) 


\section{Abstract}

This paper provides a synthesis of current data and interpretations on the crustal structure of the Pyrenean-Cantabrian orogenic belt, and presents new tectonic models for representative transects. The Pyrenean orogeny lasted from Santonian ( 84 Ma) to early Miocene times ( $20 \mathrm{Ma}$ ), and consisted of a spatial and temporal succession of oceanic crust/exhumed mantle subduction, rift inversion and continental collision processes at the Iberia-Eurasia plate boundary. A good coverage by active-source (vertical-incidence and wide-angle reflection) and passive-source (receiver functions) seismic studies, coupled with surface data have led to a reasonable knowledge of the present-day crustal architecture of the Pyrenean-Cantabrian belt, although questions remain. Seismic imaging reveals a persistent structure, from the central Pyrenees to the central Cantabrian Mountains, consisting of a wedge of Eurasian lithosphere indented into the thicker Iberian plate, whose lower crust is detached and plunges northwards into the mantle. For the Pyrenees, a new scheme of relationships between the southern upper crustal thrust sheets and the Axial Zone is here proposed. For the Cantabrian belt, the depth reached by the N-dipping Iberian crust and the structure of the margin are also revised.

The common occurrence of Iherzolite bodies in the northern Pyrenees and the seismic velocity and potential field record of the Bay of Biscay indicate that the precursor of the Pyrenees was a hyperextended and strongly segmented rift system, where narrow domains of exhumed mantle separated the thinned Iberian and Eurasian continental margins since the Albian-Cenomanian. The exhumed mantle in the Pyrenean rift was largely covered by a Mesozoic sedimentary lid that had locally glided along detachments in Triassic evaporites. Continental margin collision in the Pyrenees was preceded by subduction of the exhumed mantle, accompanied by the pop-up thrust expulsion of the off-scraped sedimentary lid above. To the west, oceanic subduction of the Bay of Biscay under the North Iberian margin is supported by an upper plate thrust wedge, gravity and magnetic anomalies, and 3D inclined sub-crustal reflections. However, discrepancies remain for the location of continentocean transitions in the Bay of Biscay and for the extent of oceanic subduction. The platekinematic evolution during the Mesozoic, which involves issues as the timing and total amount of opening, as well as the role of strike-slip drift, is also under debate, discrepancies arising from first-order interpretations of the adjacent oceanic magnetic anomaly record.

Keywords: crustal structure; subduction; collision; hyperextended margins; PyreneesCantabrian Mountains; North Iberian margin 


\section{Introduction}

The Pyrenees are a small-scale, accessible and well exposed orogenic belt that has been the subject of intensive research over a century, and serves as a geology school for numerous academic and industry groups. In addition to abundant documentation of the surface geology, the Pyrenees and their western continuation in the Cantabrian Mountains and margin have long been the target of numerous geophysical studies that aim to define their deep crustal structure. Refraction/wide-angle seismic studies in the early 80's were followed by vertical-incidence seismic reflection profiling in the late 80's and 90's (ECORS and ESCI programs, Fig. 1), which led to a series of crustal models that have become established references (see below). Although there was no complete consensus on the resolution of the lower crustal shortening and on the fate of the oceanic crust facing the Cantabrian (North Iberian) margin, models showing a persistent state of underthrusting of the Iberian plate below the Eurasian plate have endured over a decade. Latest insights into the present-day deep structure derive from passive-source seismic data (e.g. receiver-functions and tomography), which have largely supported the results of previous active-source seismic studies.

Recent understandings of the tectonic evolution of the Pyrenean-Cantabrian belt respond to the application of geological concepts of modern continental margins and hyperextension, and have had strong implications for the reconstruction of the pre-orogenic configuration (see references below). Models for the evolution of the Pyrenean orogeny must consider the feedbacks between a Cretaceous hyperextension leading to the Pyrenean-Bay of Biscay rift and the late Santonian to early Miocene compressional inversion. Major advances have been produced and can be anticipated in the frame of numerous French, Spanish and international research programs, which reflect the renewed interest in the tectonics of the Pyrenean-Cantabrian system (e.g. Topolberia, TopoEurope, Pyramid, RGF, PYROPE, Orogen). However, challenges remain as to identify the nature and extent of ancient continental margins of the Eurasian and Iberian plates and their suture, and as to estimate the total amount of plate convergence compared to its expression in thrusting and folding at the surface and at lower crustal levels. The objective of this paper is firstly to critically review the knowledge and challenges concerning the crustal structure of the Pyrenees and Cantabrian Mountains, both in the present day and in the past (during Cretaceous rifting), in the light of 
newly acquired data and modern geological concepts. Secondly, a new interpretation of the present-day crustal structure is proposed for a series of geological-geophysical transects, on the basis of recent geophysical surveys and modeling.

\section{Crustal models from the ECORS and ESCIN seismic surveys}

The crustal structure of the Pyrenees and Cantabrian Mountains has attracted the attention of geoscientists for decades. The map of Fig. 1 illustrates the wealth of deep seismic profiles that have investigated the deep architecture of this orogenic system. Early seismic refraction/wide angle data presented by Gallart et al. (1981) and Daignières et al. (1982) detected a thickened crust under the basement massif of the Axial Zone of the Pyrenees, where the Moho discontinuity was identified at a depth of $40-50 \mathrm{~km}$. In contrast, the Moho was imaged at $30 \mathrm{~km}$ under the northern Pyrenees, both domains apparently separated by a step located under the North Pyrenean Fault (NPF, Fig. 1). Accordingly, the latter was interpreted as a vertical structure cross-cutting the whole crust and separating the Iberian from the Eurasian plate. This conception dominated a first-generation of crustal models for the Pyrenees (e.g. Choukroune and Mattauer, 1978; Déramond et al., 1985; Séguret and Daignières, 1986) until the execution of deep seismic reflection surveys in the mid 80 `s.

\subsection{Results of the ECORS profiles across the Pyrenees}

The ECORS-Pyrenees seismic reflection profile, acquired in 1985-1986, crosses the central Pyrenees (Choukroune et al., 1989) (Fig. 1), being the first deep reflection profile ever acquired across an entire orogenic belt. The profile images prominent reflections of the upper crust Mesozoic and Cenozoic sedimentary basins, the top of the Variscan basement, and a set of inclined reflections that may be attributed to thrusts and normal faults in the upper to middle crust (Fig. 2A). A reflective lower crust is also clearly imaged, the base of which (the Moho discontinuity) is at 10 and $12 \mathrm{~s}$ TWT under the northern and southern forelands respectively. Under the Axial Zone, the Iberian (southern plate) reflective lower crust clearly plunges to the north, dipping under a homogeneously-thick Eurasian plate down to a depth of 20 s TWT (unmigrated; Fig. 2A). A comparable image was obtained in the ECORS-Arzacq profile across the northern half of the west-central Pyrenees (Daignières 
et al., 1994) (Fig. 1), where the base of the Eurasian lower crust, more discontinuously imaged, is at about $10 \mathrm{~s}$, whereas the edge of the Iberian plate is imaged by inclined reflections to a depth of $\sim 17$ s TWT (Fig. 2B) in an unmigrated section. Coupled with a revisit of the surface geology, the ECORS profiles led to a reinterpretation of the present-day crustal structure of the central Pyrenees. The continuation of the North Pyrenean Fault at depth as a vertical structure was disproven, being cut by a north-verging thrust fault (the North Pyrenean frontal thrust), which carries a reflective lower crustal slice. The reflection pattern revealed the indentation of the Eurasian plate to the south, driving the northward underthrusting of the Iberian deep crust, and the formation of a doubly-verging orogenic prism at mid to upper crustal levels (Roure et al. 1989; Muñoz, 1992; Teixell, 1998) (Fig. 3A, $B, C)$.

The sections reproduced in Fig. 3 were constructed on the basis of surface data and interpretations of the reflection profiles, and seek to balance the orogenic shortening at upper crustal (as deduced from geologic cross-sections) and lower crustal (as imaged in the seismic profiles) levels. The crustal shortening measured in shallow cross-sections (Roure et al., 1989; Muñoz, 1992; Teixell, 1998) exceeds that observed for the lower crust as imaged at depth on the seismic profiles. To solve this discrepancy, additional shortening mechanisms at deep levels were envisaged, e.g. a system of lower-crust thrust imbrications (Roure et al., 1989) (Fig. 3A) or the subduction of an intact portion of the deep crust to a depth not recorded by the seismics (Muñoz, 1992; Teixell, 1998) (Fig. 3B, C). Subduction of continental crust in the central Pyrenees was also supported by magnetotelluric surveys, which identify a low-resistivity zone reaching a depth of ca. $80 \mathrm{~km}$ (although the precise lower depth extent was not well resolved), attributed to partially melted subducted crust (Pous et al, 1995; Ledo et al., 2000). In the same region, seismic tomography detects a low-velocity anomaly also attributed to continental crust subducted to mantle depths (that is not found in the western Pyrenees, though) (Souriau and Granet, 1995). The problem of buoyant continental subduction was overcome by assuming that it involved only a mafic, denser lower crust (Teixell, 1998; Beaumont et al. 2000), which could have been transformed by eclogite metamorphism. It must be noted that those models only consider crustal shortening, and the potential effects of (preorogenic) differential stretching at various levels of the crust and mantle are not taken into account. No deep seismic images have been acquired in the 
eastern Pyrenees. However, while in the western part of the eastern Pyrenees an underthrust crustal root has been inferred (Vergés et al., 1995), by analogy with the ECORSPyrenees section of the central Pyrenees, this root is not detected closer to the Mediterranean coast (Díaz et al. 2016), probably due to the effect of the superimposed Oligocene to Neogene extension related to the opening of the western Mediterranean basin.

\subsection{Results of the ESCIN profiles across the Cantabrian Mountains and margin}

The ESCI Norte (ESCIN) deep seismic surveys (Fig. 1) were acquired in 1991-1993. Unmigrated vertical reflection profiles, complemented by often coincident refraction/wideangle sections, show a root of north-dipping Iberian crust under the central Cantabrian Mountains, similar to that deduced for the central Pyrenees. Accordingly, the Pyrenean root was continued to the west to the Cantabrian region (Pulgar et al., 1996; Gallastegui, 2000; Pedreira et al., 2003). The unmigrated vertical-incidence ESCIN-2 seismic profile images a reflective deep crust plunging down to 15 s TWT under the Cantabrian Mountains and margin (Fig. 4A), a remarkable finding as it implies the northward subduction of the relatively thick Iberian crust underneath the thinned North Iberian margin. As in the case of the central Pyrenees, the thinned crust of the northernmost Cantabrian Mountains and margin is interpreted to indent into the Iberian plate and to force the northward subduction of its lower part (Fig. 3D). The associated deep thrust structures eventually emerge at the surface in the southern mountain front of the Cantabrian Mountains and in the northern slope of the Le Danois bank offshore. Pulgar et al. (1996) and Pedreira et al. (2007) place a decoupling at the wedge tip within the level of the seismic middle crust of Iberia, implying that both lower crust and middle crust were subducted (Fig. 3D).

Wide-angle and refraction models along a section overlapping the ESCIN-2 profile and along the onshore continuation of the ESCIN-4 offshore profile (Fig. 1) place the Iberian Moho at depths over $50 \mathrm{~km}$ in the crustal root (Pulgar et al., 1996; Fernández-Viejo et al., 1998), although the model resulting from the former dataset does not show incident rays below 38 $\mathrm{km}$ and the latter lacks reversed shots. The models show the Cantabrian-Biscay Moho at 30 $\mathrm{km}$ under the coastline, shallowing to $16-18 \mathrm{~km}$ towards the Bay of Biscay (Fig. 4B). Further west towards Galicia, the E-W thrusts of the southern mountain front of the Cantabrian Mountains loose displacement and terminate in a set of $\mathrm{N}-\mathrm{S}$ trending transfer faults marked 
by Cenozoic intramontane depressions (Fig. 1) (Martín-González and Heredia, 2011). The crustal root thins out westward (Fernández-Viejo et al., 2000) and is no longer detected under the transfer fault zone, which shows a typical Variscan crust ca. $30 \mathrm{~km}$ thick (Téllez et al., 1993; Torné et al., 2015; Díaz et al., 2016) (see a map compilation of Moho thicknesses in Fig. 5).

\subsection{Results for the Bay of Biscay}

The northern thrust front of the Cantabrian belt west of the Pyrenees lies offshore, facing the thinned continental and oceanic crusts of the Bay of Biscay (Fig. 1), in the so-called Cantabrian or North Iberian margin. This northern front shows a jump in map view from an eastern part where it is close to the coastline, following the edge of the Basque-Cantabrian basin along the Cap Ferret canyon (FC, Fig. 1), to a western part where it shifts northwards at the foot of the Le Danois bank and the North Iberian continental slope, bordering the Bay of Biscay abyssal plain (Fig. 1). In between there is a poorly defined transfer zone which coincides with the location of the Torrelavega and Santander canyons (Fig. 1). The Bay of Biscay plain is floored by a thin, relatively high seismic velocity basement not always well defined, which has been described as an assemblage of oceanic and extremely thinned continental /transitional crust, underplated magmatic rocks or serpentinized mantle ("Bay of Biscay crust/mantle" in Fig. 1) (Déregnaucourt and Boillot, 1982; Roca et al., 2011; Tugend et al., 2014; Pedreira et al., 2015).

The nature of the boundary between the continental margin and the Bay of Biscay assemblage is controversial. For some authors a thrust system imaged in the lower continental slope by seismic profiles (NIP, Fig. 1) can be interpreted as a true accretionary prism under which the Bay of Biscay oceanic crust has subducted (Boillot et al., 1979; Déregnaucourt and Boillot, 1982; Boillot and Malod, 1988; Alvarez-Marrón et al., 1997; Ayarza et al., 2004), whereas others do not favor such a southward subduction and postulate for a continuous Moho discontinuity between the margin and the abyssal plain, at least in the longitude of the ESCIN-4 marine profile (Fig. 1) (Fernández Viejo et al., 1998; Gallastegui et al., 2002; Pedreira et al., 2015). Oceanic crust of the Bay of Biscay, as an appendix of the Atlantic Ocean, is clearly identified by the magnetic anomaly content west of longitude $6^{\circ} \mathrm{W}$ (Sibuet et al., 2004). The possible continuation to the east is undetermined, although 
another V-shaped magnetic anomaly exists from $5^{\circ} \mathrm{W}$ to $3^{\circ} \mathrm{W}$ (Sibuet et al., 2004, their Fig. $3)$, the position of which is shown in Fig. 1. Postulated evidence for oceanic subduction under the margin include an asymmetric distribution of magnetic anomalies in the oceanic floor (Srivastava et al., 1990; Sibuet et al. 2004) (Fig. 1), a band of negative free-air gravity anomalies at the foot of the slope (Lalaut et al., 1990; Ayarza et al., 2004) (Fig. 6) and a trench that reaches a depth of $\sim 5000 \mathrm{~m}$. Nevertheless, oceanic subduction has been elusive in seismic surveys, as a clear image of a subducted slab has failed to appear either in transverse reflection profiles such as the IAM-12, ESCIN-3-1 and ESCIN-4 (Fig. 1), which image well the continental margin above (Alvarez-Marrón et al., 1997), or in the more recent MARCONI profiles presented by Fernández-Viejo et al. (2011) and Roca et al. (2011). The only likely image of an oceanic slab plunging south into the mantle is provided by a set of inclined 3D subcrustal reflections in the strike-subparallel ESCIN-3-2 and 3-3 seismic profiles (Fig. 1). These reflections reach a maximum depth of 14-15 s TWT after migration, although they come from out of the plane (Ayarza et al., 1998; 2004). Further discussion on this issue is presented in section 5.4 .

\section{Contributions by recent geophysical surveys}

While active-source deep seismic experiments have not been acquired in the Pyrenees mainland since the ECORS programs, important recent contributions have arisen from the analysis of teleseismic waves recorded by Spanish and French temporary and permanent station deployments. Receiver function results by Díaz et al. (2012) are consistent with the strong indentation of the Eurasian plate to the south and also show a marked contrast between the Basque-Cantabrian and the central Pyrenees across the Pamplona transfer fault zone (PF in Fig. 1). Díaz et al. (2012) detect a Moho duplication under the western Axial Zone with the Iberian Moho signal at ca. $50 \mathrm{~km}$ depth and the lesser amplitude Eurasian Moho beneath the northern boundary of the Axial Zone at $27-29 \mathrm{~km}$. This configuration depicts the southern extent of the Eurasian Moho indentation and supports crustal wedging (e.g. Teixell, 1998). West of the Pamplona fault the Eurasian Moho was detected extending further south, under the westernmost Basque massifs and the Marbles nappe, also arguing for crustal wedging, although the Iberian Moho is not so clear in this case. To get improved insight into 
the geometry of deep interfaces in the Pyrenean crust, further station deployment has been recently carried out along three transects by the PYROPE program (see location in Fig. 1).

\subsection{PYROPE data and interpretation}

Receiver function data of teleseismic waves can be depth-converted and stacked to provide images of the lithosphere comparable to migrated reflection profiles. The resulting images show interfaces where rays at an oblique angle of incidence experience $\mathrm{P}$ to $\mathrm{S}$ conversions (i.e. discontinuities). Chevrot et al. (2015) present receiver function stack profiles for two transects coincident with the ECORS-Pyrenees (PYROPE E in Fig. 1) and Arzacq (PYROPE W) seismic reflection lines, and a third complementary transect was acquired in between (PYROPE Centre, Fig. 1). Results are reproduced in Fig. 7. Red interfaces correspond to positive amplitudes representing shear velocity decreasing upward (e.g. the Moho discontinuity), whereas the blue zones correspond to negative polarity interfaces indicating an upward increase in velocity. As these are the result of seismic waves that travel from below, receiver function data may refine the position of deep features, e.g. the Iberian and Eurasian Moho as yet obtained from reflection data.

The PYROPE receiver function profiles of Fig. 7 are in general agreement with previous seismic reflection surveys. Distinct positive polarity interfaces corresponding to the Moho of both plates can be identified. A north-dipping Iberian Moho is imaged down to a depth of ca. 60-80 km, thus supporting the subduction models of Muñoz (1992), Teixell (1998) and Beaumont et al. (2000) for the central Pyrenees. The Iberian Moho is found at a depth ca. 32 $\mathrm{km}$ in the southern end of the eastern (parallel to the ECORS-Pyrenees) and central profiles, under the Iberian foreland, and plunges northward under the Axial Zone (Figs. 7A, B). In the western profile (partly subparallel to the ECORS-Arzacq) the Iberian Moho apparently shows a less regular, staircase trajectory, although the signal is weak under the south Pyrenean foreland (Fig. 7C). The Eurasian Moho has an irregular but roughly flat-lying signature in all three profiles at a mean depth of ca. $30 \mathrm{~km}$, although it rises a few $\mathrm{km}$ in the southern end of the plate. However, the resolution of that interface may be affected by reverberations in the sedimentary layers of the Aquitanian and North Pyrenean basins (Chevrot et al., 2015). Prominent negative interfaces which overlie and are roughly parallel to the dipping Iberian Moho are interpreted by Chevrot et al. (2015) as the subduction boundary above the Iberian 
crust and underlying the Eurasian mantle wedge. These subparallel interfaces argue for a slab-shaped tract of lower crust plunging into the mantle, rather than for crustal ramps as envisaged by Roure et al. (1989), Muñoz (2002) and Mouthereau et al. (2014). The thickness of the slab varies between $14-17 \mathrm{~km}$ in average in the eastern and central profiles, and is somewhat thinner (ca. $12 \mathrm{~km}$ ) in the western profile (Fig. 7), although the resolution of the dataset is low. These values could indicate that a portion of the middle crust is involved in subduction, like in the Cantabrian Mountains model of Pulgar et al. (1996). However, they are also consistent with a 4-5 sec TWT reflective layer at the base of the crust imaged by the ECORS-Pyrenees profile. Hence, we favor that the slab is composed solely of lower crust. Thicknesses $>15 \mathrm{~km}$ for the lower crust are often reported in the literature (Rudnick and Fountain, 1995; Martínez-Poyatos et al., 2012; Thybo and Artemieva, 2013).

The position of diverging velocity discontinuities of negative polarity in the western transect (Fig. 7C) are interpreted by Chevrot et al. (2015) as further support for crustal wedging as shown in Teixell (1998) (Fig. 3C). Other negative polarity zones under the northern and southern Pyrenees in Figs 7A and C are viewed as either due to intracrustal Variscan thrusts or to reverberations under the Aquitaine basin (Chevrot et al., 2015). The angle of subduction in the eastern and central profiles ranges between $22-30^{\circ}$ whereas in the western profile it is $<20^{\circ}$, although these values must be taken as merely indicative as the method tends to underestimate dips. In addition, in the case of the western profile, the observed dip is an apparent value due to the profile obliquity to the structural grain (Fig. 1).

\subsection{Significance of high-density bodies in the crust}

The Bouguer gravity anomaly of the Pyrenean-Cantabrian region shows a long-wavelength minimum (up to -120 mgal) in the central and western part of the eastern Pyrenees (Fig. 8), which can be attributed to the crustal thickening under the Axial Zone (Bayer et al., 1996; Casas et al., 1997). Such a minimum is not found in the Cantabrian Mountains, indicating that the crustal thickening is less important. While the Pyrenean negative anomaly shows a gentle gradient towards the south consistent with flexure of the Iberian plate, as typical in several mountain ranges elsewhere (e.g. Karner and Watts, 1983), the northern side usually shows a steep gradient, flanked by a series of high-amplitude maxima (up to +20 mgal) in the central and western parts of the northern Pyrenees. These occur in a discontinuous 
fashion at the Labourd massif, at Lourdes, and south of Saint-Gaudens; Fig. 8). The asymmetry of the negative anomaly can be partly attributed to the asymmetric structure of the crustal root, with the indentation of the Eurasian crust and upper mantle into the flexed Iberian plate. But the prominence of the North Pyrenean maxima is commonly attributed to discontinuous high-density $\left(\geq 2900 \mathrm{Kg} \mathrm{m}^{-3}\right)$ bodies at shallow depth. These have been interpreted either as thrust slices (made of lower crust or upper mantle material; Torné et al., 1989; Casas et al., 1997; Vacher and Souriau, 2001; Pedreira et a., 2007; Jammes et al., 2010b) tectonically emplaced onto the North Pyrenean basement, or as autochthonous upper mantle uprises (Wang et al., 2016).

The latter interpretation has been proposed for the Labourd positive anomaly on the basis of modeling the PYROPE W data (Vp and Vs tomography). Wang et al. (2016)'s model shows a continuous mantle rise beneath a continental crust only $<3 \mathrm{~km}$ thick under the Mauléon basin (Fig. 9). If this is the case, the uplifted mantle has been preserved since the Cretaceous hyperextension and has survived the effects of the Pyrenean orogeny, having been only passively transported on a south-verging thrust. Indeed, in the receiver-function profile of Fig. 7A the Eurasian Moho is not easy to track to the south, and in the three PYROPE profiles the interface interpreted as the Moho rises to the south, which could indicate a crustal shallowing at the tip of the Eurasian plate (which was much smaller in the ECORS images, Fig. 7). However, as presented, we find a few issues with Wang et al. (2016)'s hyper-thin crust model. The accompanying geologic section hardly seems kinematically viable in terms of thrusting. Isostatic issues when accounting for the low, but existing, current mountain topography over an extremely thin crust are not yet addressed, even if just considering regional isostasy, and the gravity response of Wang et al. (2016)'s model does not overlie the Labourd anomaly, as the maximum anomaly is shifted to the north (see their Fig. 2B). Another debatable point resides in the southward extension of lower crustal and Moho reflections in the adjacent ECORS-Arzacq profile. Certainly, the deep crustal reflectivity is weak along the entire reflection line (Daignières et al., 1994), but discontinuous reflections at 8-10 s TWT (not weaker than in much of the rest of the profile) interpreted as the Moho can be traced until below the Mendibelza massif in the southern end of the profile (Teixell, 1998) (Fig. 10), and thus cross-cutting the geometry postulated by Wang et al. (2016). To the east of Labourd, the thick band of reflectivity at the deep North Pyrenean frontal thrust 
shown by the ECORS-Pyrenees profile is consistent with a slice of lower crust rocks (Roure et al., 1989; Muñoz, 1992), and thus, in order to account for the gravity pattern, the contribution of tectonically emplaced thrust units cannot be discarded there and elsewhere.

\subsection{The MARCONI surveys in the Bay of Biscay}

The latest vertical-incidence deep seismic profiles acquired in the Pyrenean-Cantabrian system are the MARCONI profiles, sampling the North Iberian margin and the Bay of Biscay plain (Fig. 1). The MARCONI profiles image the structure of the offshore sedimentary basins and intervening highs (Ferrer et al., 2008; Fernández-Viejo et al., 2011; Roca et al., 2011), but do not bring new key elements into the knowledge of the deep crust and Moho discontinuity. Coincident wide-angle/refraction data acquired with OBS and land stations are presented in Ruiz et al. (2017), and largely coincide with earlier ESCIN wide-angle results. Pedreira et al. (2015) use PmP-like reflections from ESCIN-4 (Fernández-Viejo et al., 1998) and MARCONI-1 (Ruiz, 2007) wide-angle profiles to identify a high-velocity layer under the southeastern Bay of Biscay as a mafic layer on top of hydrated mantle. This layer is represented as laterally adjacent to and partly underlying the lower crust of the margin, and is attributed to magmatic underplating. Nevertheless, as commented above, the ESCIN-4 wide angle reflection profile is not reversed, thus lacking control of $\mathrm{Vp}$ for dipping interphases, whereas the MARCONI-1 experiment has reverse data in the offshore segment but does not get reverse refractions from the mantle $(\mathrm{Pn})$. This dataset relies on the onshore structure deduced from the ESCIN-4 for the margin area, thus adding uncertainty to the models. Accordingly, the nature and structure of this high-velocity layer remain uncertain.

\section{Models for the preorogenic crustal structure}

The present-day architecture of the Pyrenean-Cantabrian orogenic belt is strongly influenced by the precursor Mesozoic rift system, which accumulated several thousands of meters of dominantly marine sediments in Cretaceous times. Cretaceous extension led to a highly segmented continental rift in the present Pyrenees and eastern Bay of Biscay, that passed laterally into (short-lived) oceanic spreading in the western Bay of Biscay (Tugend et al., 2014, and references therein). Only the southern margin of the Bay of Biscay was submitted 
to (moderate) compressional deformation, so the Bay of Biscay oceanic basin, and its eastern continuation in the Parentis continental basin (Fig. 1), are preserved. The rest of the Mesozoic basin system was intensely inverted during the Pyrenean orogeny, and information has to be retrieved from map and section restoration.

For the Pyrenees, a first generation of pre-orogenic crustal models was deduced from the ECORS geologic cross-sections and showed a well-developed rift basin, with strongly attenuated crust, but always continental in nature (Roure et al., 1989; Muñoz, 1992; Vergés et al., 1995; Teixell, 1998; Beaumont et al., 2000). Some of these models reached crustal (Airy) isostasy, taking into account the moderate synrift sedimentary thickness and paleobathymetry in the Cretaceous basin (Winnock, 1974; Teixell, 1998).

\subsection{Recent extensional models for the Pyrenees}

A breakthrough came from the application of concepts from modern passive continental margins and from a reassessment of the significance of the Pyrenean peridotite occurrences -unexplained in previous models- as witnesses of a Cretaceous hyperextension culminating in the exhumation of the mantle (Lagabrielle and Bodinier, 2008; Jammes et al., 2009; Lagabrielle et al., 2010). It is now widely accepted that the Cretaceous rifting in the Pyrenees produced extreme thinning of the continental crust, and the occurrence of Iherzolite bodies all along the northern Pyrenees attest to a central belt between the Iberian and Eurasian margins where the continental crust was removed. The subcontinental mantle lithosphere was exhumed to the base of the Mesozoic sedimentary series or even to the sea floor (Lagabrielle et al., 2010; Clerc et al. 2012; Lagabrielle et al., 2016; de Saint Blanquat et al., 2016). The new paleotectonic models accounting for mantle exhumation bear profound implications not only for the understanding of the extensional basin architecture but as well for the kinematic history of the Pyrenees, and have spurred renewed interest and intensive research in the region.

A second major output following the reassessment of the significance of the Pyrenean peridotite has been a renewed attention paid to the significance of the HT-LP metamorphism. As put forward by Vielzeuf and Kornprobst (1984), Dauteuil and Ricou (1989), and Golberg and Leyreloup (1990), the Albian-Coniacian (103-86 Ma) metamorphism in the North Pyrenean Zone is related to thermal anomalies contemporaneous with the 
crustal thinning. Recent investigations confirmed that extreme thinning occurred under a pre- and synrift sedimentary cover that deformed ductilely, thus accompanying the duration of a thermal anomaly in this central belt (e.g. Clerc et al., 2015). This makes the Pyrenean rift a rare case of synextensional HT metamorphism worldwide. An increasing paleothermometry database in the northern Pyrenees shows a generalized state of high heat flow during the mid and late Cretaceous, not only in the well-known areas of metamorphism (Fig. 11), so thermal isostasy must be taken into account when evaluating the effects of crustal hyperthinning and mantle shallowing.

West of the Pamplona transfer fault zone, Iherzolite is found in the Marbles metamorphic nappe south of the Cinco Villas basement massif (Fig. 1), indicating that the central rift axis, located in the North Pyrenean Zone to the east, experienced a major shift across the transfer zone (Tugend et al., 2014, DeFelipe et al., 2017). Seismic velocities suggest that serpentinized mantle may underlie presently large parts of the Bay of Biscay sedimentary cover, around the central oceanic domain (Roca et al., 2011, Tugend et al., 2014), although direct evidence is lacking and the absence of crust has been contested for the southern part (Pedreira et al., 2015). Tugend et al. (2014) have further mapped a paleozonation along the Pyrenees and Bay of Biscay with subdivisions of intact continental crust domains, proximal (necking) zones in the upper margins, hyperextended zones in the distal margins, and the exhumed mantle domains.

\subsection{The continental margins}

As for the crustal architecture of the ancient margins, two models have been proposed for the Pyrenees. Masini et al. (2014), based on studies in the Mauléon basin (Fig. 1), envisage the Iberian paleomargin as stretched by a system of basement-involved detachment faults and tilted blocks, resulting in a complex structure (Fig. 12A). The mantle is exhumed in the footwall of a main low-angle detachment fault that cuts the mantle lithosphere, the entire system showing a dominantly brittle architecture in regional simple shear. On the other hand, Clerc and Lagabrielle $(2014)$ and Clerc et al. $(2015,2016)$ argue for a considerable amount of ductile stretching and thinning in the central and eastern Pyrenees in what they refer as a style of "hot" paleomargins (Fig. 12B). Isolated crustal massifs may lie in between hyperthinned crust or mantle domains characterized by metamorphic cover rocks (e.g. the 
Agly massif in the sketch of Fig. 12B). One such massif shows ductile shear zones that accommodated the mid-Cretaceous extension and crustal thinning (Saint-Barthélémy massif; de Saint Blanquat et al., 1986).

In agreement with the ductile model cited above, Teixell et al. (2016) present a restored section of the west-central Pyrenees (Chaînons Béarnais) where the margins are represented as relatively smooth, boudinage-like megastructures that allowed for continuous detachment of the sedimentary cover from the crustal and mantle basement along the Upper Triassic (Fig. 12C). This conclusion is grounded on the remark by Lagabrielle et al. (2010) that many of the Iherzolite bodies of the northern Pyrenees are contained in a Triassic Keuper mélange, implying a shallow detachment at that level that allowed the sedimentary cover to slide down to overlie the subcontinental mantle, by lateral extraction of the crust. The detachment can be envisaged as a shear zone of tens to hundreds of $m$ wide that collected the Iherzolite bodies along original asperities of the exhumed mantle top. Fragments of crustal Variscan rocks from the distal margins were collected as well during the process (Corre et al., 2016). It must be underlined that the Triassic is a pre-rift salt, and the model requires a certain lateral continuity for regional detachment. This is a main constraint that leads to a smooth upper margin which allowed for regional detachment, which otherwise would be hampered by Cretaceous cross-cutting (basementinvolved) normal faults. Possible mechanisms of ductile thinning of the crustal basement underneath are discussed in Clerc and Lagabrielle (2014).

West of the Pamplona transfer fault zone, the Basque-Cantabrian Cretaceous basin is a main Cretaceous depocenter that was also significantly inverted, by buttressing against the Landes Cretaceous high (Fig. 1). The occurrence of Iherzolite in a Triassic mélange at the Marbles nappe (DeFelipe et al., 2017) (Fig. 1) indicates the existence of a central exhumed mantle belt and the gliding along an evaporite detachment, very similar to the western North Pyrenean Zone. The Parentis basin, north of the Landes horst (Fig. 1), was left relatively intact during the Cenozoic compression, and we believe it provides a good analog for Pyrenean paleomargins. The ECORS-Biscay seismic image of the Parentis basin shows a relatively symmetric synformal sag (Fig. 13), with strong crustal thinning towards the basin axis, and a rather smooth basement top draped by the Mesozoic cover (Pinet et al., 1987; Jammes et al., 2010b). This geometry and the width of the margins (about $40 \mathrm{~km}$ ) show 
strong similarities with the Chaînons Béarnais basin reconstruction by Teixell et al. (2016), leaving aside the central domain of mantle exhumation. Interestingly, a structural variation along strike in the Parentis basin was reported by Jammes et al. (2010b), where a basal cover detachment in their interpretation of the ECORS-Biscay transect passes eastward to a highangle normal fault system, as the total amount of extension decreases. In the ECORS-Biscay transect and further west, occasional sub-salt faults may not impede a regional detachment in the upper Triassic provided their offset is not exceedingly large and the Triassic salt was thick, so they are continuously draped by Mesozoic sediments as illustrated by Ferrer et al. (2012) using commercial seismic lines. Such faults may have existed in the Chaînons Béarnais basin, but their position is uncertain.

It seems likely that the two hyperextension models (Mauléon-type and Chaînons Béarnaistype) are both applicable to the Pyrenean paleomargins, depending on the area. While the Chaînons Béarnais type area requires detachment in the Triassic evaporites (Teixell et al., 2016), tilted blocks containing sub-salt lower Triassic sandstone and basement are observed in the Mauléon basin, arguing for a thinning mechanism involving basement normal faults, without a continuous décollement in the salt layer (Ducasse et al., 1986; Jammes et al., 2010a, Masini et al., 2014).

Schematic plan-view and sectional reconstructions of the Cantabrian margin and the Bay of Biscay have been presented by Roca et al. (2011), Tugend et al. (2014) and Pedreira et al. (2015). These reconstructions show a domain of Cretaceous oceanic crust in the Bay of Biscay, flanked to the south by the North Iberian continental margin. An intervening tract of exhumed mantle or underplated gabbro of uncertain width is pictured in between. The margin is often represented as a tilted-block structure with seaward dipping extensional faults (Fig. 14). The envisaged north-dipping normal faults of the margin, however, contrast with the basement-involved south-dipping thrust system that is proposed in present-day sections of the continental slope (e.g. Fig. 3D), implying mechanically complex cross-cutting relationships. The restored profile of Fig. 14 from Pedreira et al. (2016) also shows a crustal thinning zone in the proximal continental margin, later to control the crustal wedging under the Cantabrian mountains shown in the southern part of the section in Fig. 3D.

\subsection{The timing of rifting}


Post-Variscan extension in the Pyrenean-Cantabrian domain commenced already in late Carboniferous-Permian times and proceeded at varying rates during the Mesozoic, but subsidence accelerated in the Early Cretaceous -somewhat diachronically across the different continental basins (Boillot and Malod, 1982; Vergés and García-Senz, 2001)attesting for the main rifting episode. The onset of sea-floor spreading in the Bay of Biscay is more controversial. While two symmetric bands of magnetic anomaly A34 (Campanian) have long been recognized in the central part of the Bay, Sibuet et al. (2014) argue for the existence of anomalies of chrons M0 and M3 close to the Armorican and North Galicia margins, indicating that spreading could have started in Barremian-Aptian times. However, the oceanic isochron character of the purported MO bands in the North Atlantic (and their validity for plate reconstructions) has been contested (Bronner et al., 2011; Nirrengarten et al., 2017). Whatever the significance of these anomalies, a mid-late Early Cretaceous onset of spreading based on the width of the Bay of Biscay oceanic domain was postulated decades ago (Williams, 1975; Montadert et al., 1979).

Extension culminated with the crustal hyperthinning and mantle exhumation of the north Pyrenean and Basque-Cantabrian basins by Albian-Cenomanian times (Jammes et al., 2009; Lagabrielle et al., 2010). This is supported by the drowning of the Aptian (Urgonian) carbonate platforms with the onset of thick flysch sedimentation, and the occurrence of reworked Iherzolite clasts in latest Albian-Cenomanian flysch at Urdach (eastern Mauléon basin) (Debroas et al., 2010; Lagabrielle et al., 2010).

Nevertheless, these strong lines of evidence do not prevent discrepancies in the timing of mantle exhumation. Arguing for a scissor-type rotational opening of the Bay of Biscay (with convergence in the Pyrenees) in Aptian-Albian times, Vissers and Meijer (2012) propose instead that an exhumation of a ca. $320 \mathrm{~km}$-wide crustless ocean floor in the Pyrenees occurred from late Jurassic to Barremian times. Discussion on the plate kinematics of the Pyrenees and Bay of Biscay is out of the scope of this paper. Instead, we will focus in the geological implications of Vissers and Meijer (2012)'s plate-kinematic model. As the authors recognize, these implications are in apparent contradiction with several aspects of the geology of the Pyrenean-Cantabrian region. We can list first the persistence of shallow-water carbonate sedimentation (punctuated by episodes of emersion) until late Aptian-early Albian times in the northern Pyrenees and Aquitaine basin which attests for a relatively thick 
continental crust until that time. Second, convergence in Aptian times is at odds with ample documentation of regional extension in the Pyrenean-Cantabrian basins (Vergés and GarcíaSenz, 2001, and references therein). Third, the Albian marine deepening observed all along the North Pyrenean Zone, with the generalization of deep-water flysch, questions the slab break-off and consequent thermal upwelling proposed by Vissers and Meijer (2012) for that time, following subduction. And fourth, the purported subduction of more than $300 \mathrm{~km}$ of mantle slab in early Cretaceous times has left no geological signature. There was no volcanism, no accretionary prism, nor was an overthrust sedimentary lid formed, implying that the wide exhumed mantle domain was either devoid of sediments or these were completely dragged down into the subduction channel.

This is not the sole controversy concerning the plate-kinematic evolution of the PyreneanCantabrian system. The restored models of Fig. 12 simply show geometrical reconstructions to the immediate preorogenic position, for which there is relatively good consensus. They do not address the kinematics of the translations by which the two continental margins arrived at that position during the Jurassic and early Cretaceous, including the left-lateral drift of Iberia suggested by an interpretation of the Atlantic magnetic anomalies (Klitgord and Schouten, 1986; Srivastava et al., 1990). Most relevant for the hyperextended margins geometry would be the possibility of large strike-slip displacement in the Pyrenean-Bay of Biscay basin during the Albian-Cenomanian as proposed by certain reconstructions (Le Pichon and Sibuet, 1971; Klitgord and Schouten, 1986; Olivet, 1996). In contrast, other works propose that the lateral drift of Iberia essentially occurred before the late Aptian-Albian (Jammes et al., 2009; Mouthereau et al., 2014) (see plan view differences in Fig. 15). Other authors even question the validity of the magnetic anomalies in the Atlantic for plate reconstructions (Bronner et al., 2011; Nirrengarten et al., 2017). From an onshore geological perspective, conclusive kinematic evidence for the direction of basin opening during the Albian-Cenomanian in the Pyrenees is lacking. While pull-apart basin models are proposed by some authors (Choukroune and Mattauer, 1978; Debroas, 1990; Canérot, 2017, and references therein), others argue for an essentially orthogonal extension direction in the broadly E-W-trending North Pyrenean basin (Souquet and Mediavilla, 1976; Johnson and Hall, 1989; Jammes et al., 2009; Masini et al., 2014; Mouthereau et al., 2014). Field evidence for transtensional tectonics in the inland Pyrenean geological record being elusive, the 
geometrical reconstructions of the margins published so far neither provide elements to support or refute unequivocally a strike-slip component during basin opening.

The evaluation of existing plate-kinematic models in the thorough review by Barnett-Moore et al. (2016) highlights the discrepancies and uncertainties in constraints and interpretations, notably in the continent-ocean transitions in the North Atlantic and the validity of the lower Cretaceous magnetic anomalies. They conclude with the difficulties in developing a satisfactory model for the Mesozoic drift of Iberia, questioning the used constraints and emphasizing the obvious need to integrate geological observations in the Pyrenees.

After the peak episode of crustal thinning and subsidence by mid-Cretaceous times, the upper Cretaceous (from the upper Cenomanian to the Santonian) is often considered as a post-rift sequence in the Pyrenean-Cantabrian belt. This comes from the existence of a generalized mid-Cenomanian unconformity in the Pyrenees, by which basement or older Mesozoic units are onlapped by expansive (and often tabular) Cenomanian deposits. However, the abundance of fault-scarp breccias adjacent to structures like the Lakora thrust and North Pyrenean fault, and the drowning of emerged basement highs by deep-water flysch in areas as e.g. the Trois-Seigneurs massif (Fig. 1) suggest that extension continued well into late Cretaceous times, at least in the northern Pyrenees rift axis (see also discussion in Clerc et al., 2016).

\section{Updated crustal sections for the Pyrenees and Cantabrian Mountains}

Figures 16 and 17 present a series of recent and new crustal-scale cross-sections of the Pyrenean-Cantabrian belt taking into account new surface geological observations, the recent geophysical data and modeling, and the insights obtained from section restoration incorporating concepts of hyperextended margins. For the structure of the deep crust, the Pyrenean sections rely on PYROPE passive seismic data regarding decoupling between the lower crust and the middle-upper crust in the Iberian plate during the indentation of the edge of Eurasia. The present-day cross-sections coincide or run close to the crustal profiles of the ECORS, ESCIN, MARCONI and PYROPE seismic transects, and they represent our interpretation in the light of the updated state of knowledge of the Pyrenean-Cantabrian system. These sections do not cover the Eastern and Basque-Cantabrian segments of the Pyrenees, for which there is no direct deep-seismic image control. 


\subsection{The ECORS-Pyrenees section}

The section in Fig. 16A follows the trace of the ECORS-Pyrenees profile across the eastcentral Pyrenees, crossing the North Pyrenean Zone in Ariège, the Axial Zone and the southern Pyrenees along the Noguera Pallaresa valley. Descriptions and references of the surface geology can be found in Baby et al. (1988), Déramond et al. (1988), Muñoz (1992), Berástegui et al. (1993), Vergés (1993), Ford et al. (2016) and Cochelin et al. (2017). The deep structure was surveyed by the ECORS-Pyrenees and PYROPE E geophysical profiles (Choukroune et al., 1989; Chevrot et al., 2015) (Figs. 2A, 7A). Previous crustal models have been presented by Roure et al. (1989), Muñoz (1992), Beaumont et al. (2000) and Mouthereau et al. (2014). In this transect, the North Pyrenean thrusts uplift the basement massifs of Arize and Trois-Seigneurs flanked by inverted lower Cretaceous basins (Baby et al., 1988; Muñoz, 1992). Squeezed between the Trois-Seigneurs and the Axial Zone massifs is the Aulus basin, a highly strained, brecciated and metamorphosed Jurassic and Cretaceous outcrop that contains the large peridotite body of the Lherz type locality (Lagabrielle et al., 2016 and references therein). The Aulus basin is limited to the south by the North Pyrenean Fault, a steep structure that is subparallel to discontinuous remains of steeply-dipping upper Cretaceous flysch strata in the southern side, which lie on the Paleozoic of the northern Axial Zone (Fig. 16A). Restoration of the upper Cretaceous strata to the horizontal would suggest that the North Pyrenean Fault was once an inclined structure dipping north (probably an extensional fault inverted as a thrust). Interestingly, the Mesozoic rocks of the Aulus basin record a higher-T metamorphic grade than the surrounding massifs of the Axial Zone and Trois-Seigneurs (Clerc and Lagabrielle, 2014).

The basement massifs of the Axial and Nogueres Zones appear as a large antiformal stack, with steep north-dipping thrusts in the northern part and a leading edge in the Nogueres downward-facing thrusts (Séguret, 1972; Muñoz, 1992; Saura and Teixell, 2006). Separating the Variscan from the Pyrenean deformation structures in the Axial Zone is a major challenge in the absence of post-Paleozoic rocks. Muñoz (1992) interprets the root of the allochtonous Nogueres Zone in the eastern continuation of the Gavarnie thrust, implying a large displacement along the latter and a large eroded volume of Paleozoic rocks above the surface (Fig. 3B). This interpretation is discussed by Soler et al. (1998), Laumonier (2015) and Cochelin et al. (2017), who argue that the Gavarnie thrust has a much lower displacement in 
this transect and suggest that the root zone could be located to the north of the Axial Zone. This view is adopted for the section of Fig. 16A, where we root the Nogueres zone in the North Pyrenean fault, interpreted as a south-directed thrust that has been steepened by later deformation. As we will describe for the better-exposed Lakora thrust to the west, this thrust formed as an exhumed mantle domain was closed and the detached sedimentary cover was thrust southward. Certainly, the interpretation shown in the central part of Fig. $16 \mathrm{~A}$ contains a number of assumptions, as key relationships have been eroded away. But it fits well the lack of Alpine thrusts of large displacement in the Axial Zone, as well as the relatively flat envelope of the folded Paleozoic sedimentary pile and the Variscan isograds (Soler et al., 1998; Laumonier, 2015; Cochelin et al., 2017). Note that the hanging wall of the NPF is constituted by post-Paleozoic rocks (the Aulus basin). To account for the existence of Paleozoic rocks in the Nogueres thrust sheet, shortcut thrusting of an upper Cretaceous normal fault is invoked in Fig. 16A (eroded). Similarly, a complex preorogenic structure may explain the absence of Cretaceous rocks in the Nogueres footwall (see further discussion in $6.1)$.

South of the Axial and Nogueres zones, the south Pyrenean cover is deformed into an imbricate fan of thrusts detached in the Triassic (Séguret, 1972; Muñoz, 1992; Vergés, 1993). Muñoz (1992) interprets the northern border of these cover units as a south-dipping backthrust formed by indentation of the Nogueres thrust units, in contrast to the former interpretation by Séguret (1972) as a major, south-directed décollement thrust. The interpretation by Muñoz (1992) is partly guided by the subtractive nature of the fault surface (which places Jurassic and Cretaceous rocks over the Triassic). Although the passive backthrust displacement is viable, the observed truncation relationships could have also been originated by complex salt diapirism of the Triassic Keuper as documented in the Noguera Ribagorçana valley by Saura et al. (2016).

The interpretation of the deep crustal structure shown in Fig. 16A is guided by the recently acquired PYROPE data. The receiver function image of Fig. 7A suggests a subducted slab of Iberian lower crust, rather than a crustal footwall ramp as interpreted in Roure et al. (1989) and Mouthereau et al. (2014). The plunging slab gently thins northwards (Figs. 7A and 16A), probably as an inheritance of the former extensional structure. The detachment of the lower crust implied by this geometry is solved by wedging of the Eurasian crust, as inferred for the 
profiles in the west-central Pyrenees by Chevrot et al. (2015) and Teixell et al. (2016) (see below). The edge of the Eurasian plate is not imaged by seismics and hence the position of the wedge tip is uncertain: it could be placed in the deep continuation of the Rialp thrust (Beaumont et al., 2000), or further south as shown in Fig. 16A. We favor the latter interpretation because the first would still imply a ramp of the upper-middle crust in the continuation of the lower crustal subduction plane, which is not supported by the almost parallel subduction and Moho convertors in the receiver function image (Fig. 7).

\subsection{The Nestes-Aínsa section}

This section follows the trace of the PYROPE Centre profile (Fig. 1), on which the interpretation of the deep crustal structure is based. The section crosses the Aquitanian foreland, the North Pyrenean Zone along the Nestes valley, the Axial Zone, and the Aínsa basin in the southern Pyrenees. A complete cross-section of the upper crust in the area was presented by Martínez-Peña and Casas-Sainz (2003). More details of the geology can be found in Debroas (1990), Lopez-Mir et al. (2014), Muñoz et al. (2013) and Santolaria et al. (2014). Subsurface data in the Aquitanian basin indicate that foreland structures are mainly related to deep thick-skinned thrusting associated with shallower thrusts and salt structures in the post-Paleozoic cover. Basement thrusts may be interpreted as reactivated Permian normal faults or Variscan thrusts. The North Pyrenean Zone is characterized by a system of steep faults and tight upright folds, bound to the north by the North Pyrenean Frontal thrust (NPFT), which appears strongly controlled by Mesozoic salt tectonics (Fig. 16B). The Barousse Paleozoic basement high separates two bands of metamorphosed Jurassic and Cretaceous rocks. To the north is the Lortet metamorphic zone (External Metamorphic Zone, EMZ; Fig. 16B), composed by the Albian flysch basin of Baronnies containing Iherzolite bodies (e.g. Avezac, Debroas, 1990; Azambre et al., 1991), and to the south is the Montillet metamorphic zone (Internal Metamorphic Zone, IMZ; Fig. 16B), composed dominantly of Jurassic marble and Albian flysch and bound to the south by the North Pyrenean fault. This fault appears as a steep thrust by which the metamorphic zone is in contact over Permian, Triassic and Upper Cretaceous north-dipping strata of the northern Axial Zone.

The stack of basement-involved thrust sheets of the Axial Zone, described by Martínez-Peña and Casas-Sainz (2003), is incorporated in Fig. 16B. Most outstanding is the exposure of the 
Gavarnie thrust, which is folded by underlying basement thrusts. A major tectonic element in the sedimentary cover of the southern Pyrenees is the Cotiella thrust sheet, which has been recently described as an inverted Mesozoic basin with spectacular extensional salt tectonic structures formed during the late Cretaceous (López-Mir et al. 2014). The Cotiella thrust sheet appears as an isolated klippe (Séguret, 1972), for which a relationship with one of the thrusts of the Axial Zone is not straightforward. Martínez-Peña and Casas-Sainz (2003) interpret it as linked with the Millares and Bielsa thrusts (see location in Fig. 16B), an interpretation that requires a complex backthrust indentation of the Cretaceous-Eocene strata of the Cotiella footwall to account for the present disconnection between these thrusts. As an alternative, the root of the Cotiella thrust in Fig. 16B is here placed in the North Pyrenean fault zone.

In the footwall south of the Cotiella massif, the Eocene of the Aínsa basin is characterized by obliquely-trending (i.e. NW-SE to N-S) folds and thrusts, which according to paleomagnetic data from Muñoz et al. (2013) have experienced an important vertical-axis rotation during thrusting. Late diapiric structures with Oligocene-Miocene activity exist to the south, until the South Pyrenean Frontal thrust that is largely buried by Miocene sediments on this transect (Santolaria et al., 2014).

The PYROPE Centre seismic profile of Fig. 7B reveals, for the Nestes-Aínsa section, a crustal structure that is very similar to that described above for the east-central Pyrenees. A northward-dipping slab of Iberian lower crust plunges into the mantle to a depth of ca. 80 $\mathrm{km}$, although the signal of the plunging Moho discontinuity is weaker than in the eastern transect.

\subsection{The Chaînons Béarnais-Jaca section}

The cross-section in Fig. 16C depicts the crustal structure of the west-central Pyrenees across the Chaînons Béarnais (North Pyrenean Zone), the western Axial Zone and the Jaca thrusttop basin in the southern Pyrenees (Fig. 1). This section line runs 10-15 km east of the AnsóArzacq crustal transect of Teixell (1998), and construction details are given in Teixell et al. (2016). Descriptions and references of the surface geology can be found in Labaume et al. (1985), Teixell (1996) and Lagabrielle et al. (2010), and the deep structure derives from the projection of the ECORS-Arzacq and PYROPE W geophysical profiles (Daignières et al., 1994; 
Chevrot et al., 2015). Almost the entire transect of this segment of the Pyrenees is, in the near-surface, characterized by south-verging thrusts and folds, with the exception of the North Pyrenean Frontal thrust zone. Although there is a generalized detachment at the level of the Upper Triassic in the southern Pyrenees, thick-skinned basement thrust sheets with a lesser degree of overlap compared to the eastern sections uplift the northern Jaca basin and the Axial Zone (see details of the relationships of those and the emerging syn-sedimentary cover thrusts of the Jaca basin in Labaume et al., 2016a). The Axial Zone is separated from the North Pyrenean Zone by the south-verging Lakora thrust, the largest-displacement (ca. $20 \mathrm{~km}$ ) fault exposed on the transect, carrying a thin thrust sheet composed of the IguntzeMendibelza basement massifs and their Cretaceous conglomerate and flysch cover. To the north is the Chaînons Béarnais belt, a system of Jurassic to Lower Cretaceous carbonate antiformal/thrust ridges separated by synclines with thick Cretaceous flysch. To the west, the Chaînons Béarnais plunge laterally under the Mauléon basin, dominated by lower Cretaceous flysch (Jammes et al. 2009; Masini et al., 2014). Section construction constraints indicate that the Chaînons Béarnais belt is detached in the Upper Triassic, which crops out in the cores of the antiformal/thrust ridges and contains several continental basement and Iherzolite slices. Folding was already initiated during Jurassic-Early Cretaceous extension resulting from the rising and downbuilding of diapiric salt walls and minibasins (Canérot, 1988; Labaume and Teixell, 2014). The underlying basement can be inferred to dip northwards, cut by thrust faults, until it attains the regional elevation of the Aquitaine basin (Fig. 16C; Lagabrielle et al., 2010; Teixell et al. 2016). The North-Pyrenean Frontal thrust (NPFT) appears in the near-surface as an imbricate fan of poorly emergent north-verging thrusts, and is interpreted to continue along a south-dipping crustal ramp at depth (Teixell, 1998; Teixell et al., 2016). North of the NPFT is the Arzacq basin, a portion of the ancient continental margin, which was only moderately inverted by the compression. An intervening horst, with a reduced Mesozoic succession, is detected by subsurface data (the Grand Rieu ridge, Fig. 16C).

The depth and extent of the lower crust and Moho from ECORS-Arzacq and PYROPE data in the west-central Pyrenees shows a slab of Iberian lower crust plunging into the mantle to a depth of ca. $60 \mathrm{~km}$ (Figs 7C, 10). The resolved geometry of the deep NPFT and the referred geophysical images favor a model of crustal-scale indentation similar to that proposed by 
Teixell (1998) and Chevrot et al. (2015). The observations do not support the Lakora thrust dipping north to offset the lower crust and Moho (e.g. Daignières et al. 1994; Jammes et al., 2009), nor they provide evidence for the Guarga thrust (Fig. 16C) oversteepening downwards to link with the lower crust and Moho offset (e.g. Muñoz, 2002). According to the present-day structure shown in Fig. 16C, Teixell et al. (2016) identify the former Iberian continental margin in the Lakora thrust sheet and in the present-day basement beneath the Chaînons Béarnais. It follows that the Eurasian plate margin must be largely buried under the deep ramp of the NPFT, which can be considered as the Pyrenean suture at the level of the crustal basement. As the displacement of the NPFT system in the overlying Cretaceous rocks is relatively minor and cannot account for the large translation on the deep basement ramp, part of this translation must be transferred backwards into the south-directed cover detachment of the Chaînons Béarnais, ultimately emerging in the Lakora (shortcut) thrust (Fig. 16C).

\subsection{Sections across the Cantabrian Mountains and Bay of Biscay}

The section in Fig. 17A follows the trace of the ESCIN-2 profile across the Cantabrian Mountains, and its northern continuation in the MARCONI-1 profile across the North Iberian margin and Bay of Biscay (Fig. 1). Descriptions and references of the upper crustal structure can be found in Alonso et al. (1996), Gallastegui (2000) and Cadenas and Fernández-Viejo (2016). Previous crustal models have been proposed by Pulgar et al. (1996), Fernández-Viejo et al. $(1998,2000)$ Gallastegui $(2000)$ and Pedreira et al. $(2003,2015)$, and are synthesized in Fig. 3D. With the near-surface geology described by the above-mentioned authors, using constraints provided by free-air gravity anomaly modeling, we propose a new interpretation of the crustal structure. This interpretation takes into account the as yet unpublished migrated section of the ESCIN-2 vertical incidence seismic profile (Fig. 18; see table 1 for processing parameters), and the upper crustal structure imaged in the MARCONI-1 profile (Fernández-Viejo et al., 2011; Roca et al., 2011).

The root of Iberian crust under the Cantabrian Mountains is imaged on the migrated ESCIN-2 profile with a gentle northward dip until a depth of ca. 14 s TWT. The profile images a slablike dipping layer some 4-5 s TWT thick ( 12-15 km), similar to that imaged in the Pyrenean profiles, and that we hence attribute to lower crust only, at variance with previous crustal 
models where the middle crust was interpreted to subduct (e.g. Fig. 3D). It must be pointed out that the Cantabrian crustal root does not coincide with a prominent Bouguer gravity anomaly minimum like in the central Pyrenees, but with a positive gradient (Fig. 8) that rather reflects the thinning of the continental margin (Figs. 8, 19B). Modeling of the free-air gravity anomaly, coupled with the moderate amount of post-Variscan shortening in the Cantabrian Mountains, suggests that the Cantabrian lower crustal root most probably reaches a depth of ca. $45 \mathrm{~km}$ (Figs. 18, 19A). This interpretation would agree with recent crustal models of Torné et al. (2015), Díaz et al. (2016) and Palomeras et al. (2017) where the thickness of the crust in the area is of $40-45 \mathrm{~km}$, and differs from those of Pedreira et al. (2015) where the root reaches greater depths of $60-90 \mathrm{~km}$.

Previous wide-angle data by Fernández-Viejo et al. (1998) and gravity modeling in the offshore Cantabrian shelf indicate a progressive northward thinning of the upper-plate continental crust, which is consistent with a thick Mesozoic accumulation in the Asturian basin south of the Le Danois bank (Fig. 17A) (Cadenas and Fernández-Viejo, 2016). The Le Danois bank is a bathymetric promontory near the shelf break which coincides with a basement high, covered discontinuously by a thin Mesozoic-Tertiary succession (Boillot et al., 1979). The bank is marked by a very strong gravity maximum, which cannot be explained solely by the bathymetry and the reduced sedimentary cover, but necessitates a thin and dense crust underneath. Interestingly, dredging in the bank collected clasts of Precambrian granulites and other high-grade rocks in a conglomerate of supposed Mesozoic age (Capdevila et al., 1980), suggesting that the basement in the bank may be at least partly formed by high-density rocks that can contribute to the gravity maximum (Fig. 19A). These rocks could have been exhumed during the Cretaceous extension in the distal continental margin. The structure of the basement highs and lows represented by the Asturian basin and the Le Danois bank has been previously interpreted as a thrust system (Boillot et al., 1979, Gallastegui et al., 2002), or as a system of horsts and grabens, with only moderate and local inversion (Soler et al., 1981; Cadenas and Fernández-Viejo, 2006). Models based in thrusting depict the upper continental slope bordering the bank as a northward-tapering thrust wedge (Gallastegui et al., 2002, Roca et al., 2011), although thrusts are not unequivocally imaged in reflection profiles. By analogy with the interpretation we will propose for the western North Iberian margin at the IAM-12 line location (Fig. 17B), and in view of the general thinned 
crustal structure of the margin, we favor a dominant extensional mechanism and interpret the bathymetry of the continental slope as relict of the Cretaceous passive margin.

On the other hand, a thrust system is convincingly imaged at the foot of the slope, more than $30 \mathrm{~km}$ wide, in the MARCONI-1 profile (e.g. Fernández-Viejo et al., 2011; Roca et al., 2011). It coincides with a gravity low (Fig. 19A), as in the proximity of the IAM-12 line at the foot of the Ortegal spur (Figs. 6, 19B). This structure is often reported as an accretionary wedge, although its nature, i.e. whether formed by continental crust or offscraped sediments, is uncertain. Gallastegui (2000) describes it as a tectonized belt, and suggests that basement is involved. This would be consistent with the relative high densities needed to fit the gravity anomaly along the ESCIN-2-MARCONI-1 transect (Fig. 19A), and with a relative gravity high existing in the middle of the low which requires a body of high-density rock (a thrust unit of ancient exhumed mantle/lower crust in the distal margin or a Variscan feature?). The base of slope thrust system is fossilized by late Neogene to Quaternary deposits attesting for its current inactivity.

The nature of the basement under the sediments of the Bay of Biscay abyssal plain is prone to different interpretations. A Moho discontinuity could not be imaged by any of the ESCIN and MARCONI reflection profiles across the area, which are characterized by strong seabottom multiples. Using wide-angle data, Fernández-Viejo et al. (1998) modeled a thin crust with relatively high seismic velocities (up to $7.2 \mathrm{~km} / \mathrm{s}$ at the base), that has been subsequently interpreted as thinned continental lower crust or "transitional crust" (Gallastegui, 2000, Roca et al., 2011), as underplated gabbro (Pedreira et al., 2015), or similarly as intrusions of mafic rocks in a partly exhumed and serpentinized mantle (Ruiz et al., 2017). Using lower velocities more characteristic of continental crust would require modeling an even thinner crustal layer to fit the travel times. On the limited constraints available, and in view of the tabular geometry of the body and its likely physical properties (high velocity and density), we interpret it as oceanic crust. Although at this longitude there is a pair of magnetic anomalies, arranged with a V-shape with branches in both sides of the bay (Fig. 1), there is no agreement that they represent oceanic crust, despite Deregnaucourt and Boillot (1982) having mapped the oceanic crust extending to there. 
The strong positive/negative free-air gravity anomaly pair observed in this transect of the North Iberian margin is akin to that observed along the IAM-12 transect further west, and we attribute both to oceanic subduction. Interestingly, such strong anomaly pairs are not observed in the Armorican conjugate passive margin that borders the Bay of Biscay to the north (Fig. 6). Hence, in our interpretation for the ESCIN-2-MARCONI-1 transect in Fig. 17A we represent a subduction zone of Bay of Biscay oceanic crust, although of probable limited extent at this longitude. In this model, the thrust prism at the foot of the North Iberian margin is entirely allochtonous over flexed oceanic crust, and would correspond to the edge of the Cretaceous continental margin. This interpretation differs from previous ones where the prism was shown as made up of upper crustal material detached from an underlying lower crust (Fig. 3D), an interpretation that requires that the upper crust pinched out during the Cretaceous extension while the lower crust/underplated gabbro unit was continuous.

West of longitude $6^{\circ} \mathrm{W}$ there is general agreement in the oceanic nature of the Bay of Biscay plain. As we discussed above, there is neither complete consensus on the extent to which this oceanic crust has experienced subduction under the North Iberian margin. Alvarez Marrón et al. (1997) interpret the IAM-12 seismic reflection profile offshore northern Galicia (Fig. 1) showing a small portion of oceanic crust thrust under the continental margin, attached to the subcontinental Moho and leaving no mantle wedge in between. The out-ofthe-plane reflections at 14-15 s TWT in the ESCIN-3-2 and 3-3 seismic profiles have been interpreted as the top of an oceanic slab penetrating into the mantle by Ayarza et al. (1998, 2004). Due to the obliquity of the profiles with respect to the structure, their true depth can only be estimated after seismic modeling, resulting in ca. $40 \mathrm{~km}$ (Ayarza et al., 2004). This is consistent with earthquake foci in the area up to a depth of $44 \mathrm{~km}$ (op. cit.). Fig. 17B is an interpretative sketch of the active margin along the IAM-12 line according to these results and to new gravity modeling shown in Fig. 19B. The geology of the upper crustal sedimentary basins and highs in the continental and oceanic domains is based on tracings of the IAM-12 profile by Alvarez Marrón et al. (1997) and Tugend et al. (2014). The As Pontes and other faults are the offshore projections of the traces reported in Martín-González and Heredia (2011). The free-air gravity anomaly in the margin is irregular, with relative highs and lows. This requires invoking upper-crustal basement features to obtain a good fit of the anomaly, represented in Fig. 19B as the offshore continuation of Variscan granites and the 
Ordenes mafic thrust complex, well known onshore. The thrust prism at the base of the slope is modeled in Fig. 19B as a tectonized belt of limited areal extent including basement and sedimentary rocks, whereas the general bathymetry of the margin is interpreted as a relic of the Cretaceous extensional (passive) margin. Tugend et al. (2014) propose that the tip of the Bay of Biscay oceanic slab could be composed of serpentinized mantle that had been exhumed during the Cretaceous extension, represented in their interpreted IAM-12 profile at shallow depth directly under the tectonized thrust prism. In our model with more deeply-penetrating oceanic slabs in the sections of Fig. 17, the ancient belt of exhumed mantle that may have existed would lie at the leading edge of the slab, now subducted into the mantle.

Considering the Cantabrian Mountains and North Iberian margin in general, it is noteworthy that the negative free-air anomaly minima at the foot of the margin (Fig. 6) approximately relays with the crustal thickening onshore (Fig. 5). This suggests that there might be a westward increase in the ocean-continent boundary deformation, indicating a change in the main accommodation mechanism for plate convergence from continental crust imbrication to oceanic subduction.

\section{Feedbacks between rifting and orogenic models}

\subsection{Extensional heritage in the style of inversion}

It should be underlined that the paleoprofiles of the Pyrenean rift in Fig. 12 imply that the domains where the crust was extremely thinned or totally removed were covered by a thick succession of Triassic to Cretaceous evaporite, carbonate and flysch deposits (e.g. the Mauléon, Chaînons Béarnais and Aulus basins; Jammes et al., 2009; Lagabrielle et al., 2010, 2016; Boucheville; Clerc et al., 2015, 2016). During the closure of the mantle domain by subduction (previous to the collision of the margins), this buoyant sedimentary lid was detached and thrust in a pop-up fashion onto both continental margins (Mouthereau et al., 2014; Teixell et al., 2016). In the case of the Chaînons Béarnais, the thrust detachment used the previous extensional detachment along the upper Triassic evaporites. 
The Lakora thrust sheet begun to form in this thin-skinned thrusting stage, and so did, in our interpretation, the Nogueres thrust sheet (and by extension the south Pyrenean cover thrusts of Pedraforca and Cotiella). The existence of upper Paleozoic rocks in the Lakora and Nogueres units, forming thin sheets, suggests some form of shortcut thrusting so basement could be incorporated. Fig. 20 shows a preliminary restoration of the ECORS-Pyrenees section where the Nogueres Paleozoic units are plucked from the upper part of the Axial Zone. The existence of upper Cretaceous flysch in the footwall of the North Pyrenean fault, where we propose to root the Nogueres thrust, suggests that these units were forming part of a late Cretaceous basement high, cut by a shortcut thrust. This style is similar to that envisaged for the Lakora thrusting that emplaced the thin basement sheet of the IguntzeMendibelza massifs further west (Figs. 12C and 16C; Teixell et al., 2016), and marks the style of early, thin-skinned thrusting associated to early tectonic inversion of the central Pyrenees paleomargins, characterized by cover décollement or thin-basement involvement.

In their frontal parts, the Lakora and Nogueres thrusts ramped up by inversion of the southern basin-bounding normal faults formed during the Cretaceous (e.g. Bóixols thrust; Muñoz, 1992; Lakora klippe; Teixell, 1996). More external thrusts in the Pyrenees are more of a thick-skinned style, imbricating the thicker continental margin basement, e.g. the rift margin in the southern Pyrenees (e.g. Gavarnie, Guarga, Orri, Rialp thrusts, Fig. 16), or with a basement-involved inversion mode in the North Pyrenean massifs. These basement thrusts often connect with cover detachments before emerging to the surface, which splay into imbricate fans composed of outward-tapering Mesozoic-Paleogene rocks (Fig. 16).

\subsection{Magnitude of convergence}

The comparison between published crustal sections and restored models to Cretaceous times has given estimates of the total orogenic shortening across the Pyrenean-Cantabrian belt in response to convergence of the Iberian and Eurasian plates. An independent way to estimate the magnitude of convergence consists of map view reconstructions of Iberia and Eurasia trajectories based on plate reconstruction criteria (e.g. oceanic magnetic anomalies, rotation poles). In addition to the uncertainties in the early Cretaceous history arising from the diverse interpretation of the J-anomalies in the North Atlantic (chrons M0 to M4; Sibuet 
et al., 2004; Bronner et al., 2011; Nirrengarten et al., 2017), the reconstructed separation between the Iberian and Eurasian plates in the late Cretaceous, previous to the widely accepted onset of the Pyrenean orogeny at $\sim 84 \mathrm{Ma}$, range from $200 \mathrm{~km}$ in the east of the Pyrenees and $100 \mathrm{~km}$ in the west (Roest and Srivastava, 1991) to $180 \mathrm{~km}$ (Mouthereau et al., 2014) or 150-140 km in the central Pyrenees (Olivet, 1996; Barnett-Moore et al., 2016). To this discrepancy we can affix the purported separation of $400 \mathrm{~km}$ consumed by scissor-like convergence since the early Cretaceous envisaged by Sibuet et al. (2004) and Vissers and Meijer (2011), discussed above. It follows that plate reconstructions provide a first-order approximation of the order of magnitude, but are unreliable to extract precise amounts of convergence to which the Pyrenean geology must be fitted.

Unfortunately, neither is the restoration of balanced cross-sections free of limitations. There are significant uncertainties in structural interpretation (e.g. by incomplete exposure of matching fault cut-offs, overlooked internal strain, vertical-axis rotations, etc.). This is particularly challenging with crustal-scale sections, where diverse levels of erosion and exposure make it difficult to have a thorough control of all the aspects that impact shortening calculations. The result is that crustal sections have cumulative errors which may amount to tens of kilometers, and experienced geoscientists can arrive at markedly different values along the same line of section. As an example, the section along the ECORS-Pyrenees profile, probably the most documented section of the system, has been reported to record a crustal shortening of $92 \mathrm{~km}$ (Mouthereau et al., 2014), $100 \mathrm{~km}$ (Roure et al. (1989), or 147165 km (Muñoz, 1992; Beaumont et al. 2000). In what follows we present a critical summary of published shortening values from the restoration of crustal-scale sections for the areas represented in Figs. 16 and 17, although it is not our objective here to arrive at a new database of shortening variation across the length of the Pyrenean-Cantabrian belt.

It is worth pointing out that, in order to calculate the total plate convergence, an extra shortening, not recorded by the crustal basement, must be added to the crustal shortening values. This extra shortening is associated to the closure of the exhumed mantle domain between the two Mesozoic continental margins (Lagabrielle et al., 2010; Vissers and Meijer, 2011; Mouthereau et al, 2014; Teixell et al., 2016). In the ECORS-Pyrenees transect the width of the exhumed mantle domain, and thus the extra shortening inferred, ranges from a conservative value of ca. $15 \mathrm{~km}$ (Lagabrielle et al. 2010; Jammes et al., 2014), to $50 \mathrm{~km}$ 
(Mouthereau et al., 2014), or to more than 300 km (Vissers and Meijer, 2000). Wherever preserved, the sedimentary cover of the exhumed mantle domain does record the total magnitude of convergence (see below), and should in principle yield more reliable results than extrapolating plate reconstructions, provided that its extensional structure is well understood (be it in the form of normal faulting, internal strain or extensional denudation, e.g. Lagabrielle et al., 2010). Unfortunately, for the ECORS-Pyrenees transect, the surface geology of the Aulus basin, originally lying on the exhumed mantle, provides insufficient constraints to estimate the shortening it has experienced and to figure out the original width of the mantle domain, introducing a real uncertainty in the calculations (e.g. Mouthereau et al., 2014). For the Chaînons Béarnais-Jaca transect, the width of the peridotite domain in the reconstruction by Teixell et al. (2016) was drawn to a minimum value following the restored separation of the Iherzolite bodies outcropping there, that is ca. $15 \mathrm{~km}$. Enlarging the peridotite domain would require adding more thrust displacement to the NPFT or to the Licq and frontal Lakora faults (Fig. 16C), not always in accordance with geological data (Teixell et al., 2016).

For the ECORS-Pyrenees section, the discrepancies highlighted above arise not only from the difficulty in resolving thrust displacements in the Axial Zone basement, but also from the South Pyrenean cover thrust system, e.g. the high-range estimates by Muñoz (1992) and Beaumont et al. (2000) have been contested by minimizing duplication of the JurassicCretaceous succession under the Serres Marginals thrusts (Vergés, 1993), or by reinterpreting the significance of wells as the Comiols-1 well and relocating the footwall cutoff of the Tertiary of the Ebro Basin under the southern Pyrenees (Teixell and Muñoz, 2000; Mouthereau et al., 2014). It must be emphasized that the range of 93-165 km mentioned above does not account for the shortening associated to the closure of the exhumed mantle domain. As discussed above, in our model of Fig. 16A, we discard the Gavarnie thrust as the root of the Nogueres units, which we relate to the North Pyrenean fault. This implies a major change not only in the displacement transfer relationships but also in the amount of shortening. The reconstruction in Fig. 20 points to $105 \mathrm{~km}$ of crustal shortening for the ECORS-Pyrenees transect, considering bed lengths. In order to account for the relatively thick thrust units of the northern Axial Zone, which likely come from thinned crust of the Iberian margin, we assume the estimation from Beaumont et al. (2000) of ca. $20 \%$ of alpine 
ductile thickening, which is consistent with the strong cleavage and high strain in the area. This high strain was illustrated and interpreted as mainly Variscan by Cochelin et al (2017), but could have been developed partly during the Pyrenean inversion. With the given present-day length, this would represent ca. $5 \mathrm{~km}$ of extra shortening to the section. Finally, if we arbitrarily assume the original width of the exhumed mantle domain and Aulus basin in $15 \mathrm{~km}$ (see above), we conclude with a total convergence of $125 \mathrm{~km}$ for the ECORSPyrenees transect. As with the other published estimations, this value may be taken with awareness of the uncertainties and due caution.

Crustal shortening (without the mantle component) for the Nestes-Aínsa area was estimated in ca. 100 km by Martínez-Peña and Casas-Sainz (2003), on the basis of a cross-section which differs from ours in Fig. 16B in the relationships between the main thrusts of the Axial and South Pyrenean zones. However, precise values of shortening by the South Pyrenean thrusts in this transect are hampered by the obliquity of the structures and the postulated large vertical axis rotations (Muñoz et al., 2013). Restoration of the Chaînons-Béarnais Jaca transect of Fig. $16 \mathrm{C}$ results in a total shortening of $114 \mathrm{~km}$ according to Teixell et al. (2016), a magnitude that takes into account the closure of a ca. $15 \mathrm{~km}$-wide exhumed mantle tract as explained above. This represents $\sim 20 \mathrm{~km}$ more crustal shortening than calculated for the Ansó-Arzacq section traced 10-15 km to the west by Teixell (1998). A fraction of this difference may be explained by a shortening reduction to the west in the Jaca basin, expressed by the rotational emplacement of the southern thrust front of the External Sierras. Another fraction is associated to the extensional denudation of the Mesozoic in the continental margins in parallel to the opening of the exhumed peridotite domain (Fig. 12), which was not considered before. Fault cut-offs and thrust faults are generally well constrained in the area, largely dominated by post-Paleozoic rocks: accordingly, the main source of uncertainties in shortening estimates are restricted to the bedding-parallel Licq fault in the northern Pyrenees, and to a not accounted component of strain in the northern part of the Jaca basin and the NPFT zone. If we compare these values with Mouthereau et al. (2014)'s and our estimations (cf. above) for the ECORS-Pyrenees transect, there seems that shortening does not show large variations from east to west along the central Pyrenees.

A recent estimate of shortening across a section of the Basque-Cantabrian basin is given by Quintana et al. (2016), who on the basis of restoration of the upper crust calculate the total 
magnitude, in ca. $100 \mathrm{~km}$. For the Cantabrian Mountains and margin the calculation of alpine shortening is more difficult due to the little constrained thrust architecture of the continental slope offshore (the NIP of Fig. 1), although Gallastegui (2000) and Pedreira et al. (2015) arrive at similar total values close to $100 \mathrm{~km}$, the latter considering that continental subduction placed the crustal root at depths around $70-90 \mathrm{~km}$. Our new interpretation of the magnitude of lower crustal subduction under the Cantabrian Mountains and of the extensional structure of the continental slope implies that the published values may be overestimated in these structures, although the oceanic subduction here proposed adds extra shortening not considered before. Recognizing the uncertainties, the amount of displacement of the subduction and thrust structures of the Cantabrian models of Figs 17A and B imply a comparable total shortening of $\sim 90$ and $\sim 85 \mathrm{~km}$ respectively.

\subsection{Vertical distribution of shortening}

We have seen that, since the acquisition of the ECORS-Pyrenees reflection profile, the shortening recorded by the upper crust exceeds the one imaged for the lower crust by seismic profiling, and that shortening balance was solved by deep crustal imbrication or subduction. This problem was revisited by Teixell et al. (2016) for the Chaînons-Béarnais-Jaca section on the basis of the recent PYROPE profiles. The total $114 \mathrm{~km}$ of shortening based on restoration of the upper crustal sedimentary cover, well preserved in or near that transect, differs from the shortening of the lower crust and Moho (ca. $50 \mathrm{~km}$ if we consider linelengths), which is interpreted as related to the effect of lower crustal removal during preorogenic hyperextension (Teixell et al., 2016). This interpretation is guided by the limited depth extent of the present-day subducted lower crust imaged by receiver functions (Fig. 7), and by the occurrence of only mid-upper crustal rocks in the continental fragments intermixed with the peridotite slices in the Chaînons Béarnais area (Lagabrielle et al., 2010; Corre et al., 2016). As an alternative, it may be argued that the PYROPE receiver function profiles do not image the true depth reached by the subducted lower crust, which may have arrived at greater depths beyond detection. However, other geophysical methods have failed in finding the Pyrenean crustal roots at greater depths (Torné et al., 2015; Díaz et al., 2016; Palomeras et al., 2017). For that interpretation, we propose that the removal of lower 
crust during the Cretaceous rifting was probably due to lower crust break-up while the middle-upper crust was ductilely stretched, with good balance between both modes of extension in the restoration of Fig. $12 \mathrm{C}$.

Certainly the shortening estimate at the deep crustal level does not take into account a possible component of ductile thickening of the lower crust. However, the relative homogeneous thickness of the reflective deep crust imaged by the ECORS-Pyrenees reflection profile (e.g. Choukroune et al., 1989; Berástegui et al., 1993) (Fig. 2) suggests that in the Pyrenees this component is not too large and allows first-order estimates as if the lower crust behaved like a relatively strong beam. This assumption is nevertheless markedly different from the interpretation by Quintana et al. (2016) for the Basque-Cantabrian basin, who propose the opposite: an excess sectional area of the lower crust (recording $122 \mathrm{~km}$ of shortening vs. only $100 \mathrm{~km}$ in the upper crust), which is solved by supposing a displacement transfer towards Iberia along an upper crustal detachment. Their interpretation is based on the assumption that the lower crust was homogeneously thickened during the orogeny, although for the moment we lack a seismic image of the deep crust in the area to support this, nor is the original thickness of the lower crust constrained as to allow extraction of reliable inferences from area balance considerations.

\subsection{Kinematic evolution of the orogeny}

The kinematic evolution of the Pyrenean orogeny at crustal scale has been addressed by means of stepwise restorations of specific transects by Beaumont et al. (2000) and Mouthereau et al. (2014) (ECORS-Pyrenees section), Vergés et al. (2002) (eastern Pyrenees) and Teixell et al. (2016) (west-central Pyrenees). Timing of the compressional structures in these works is based on tectonics-sedimentation analysis and thermochronology, which reveal the key steps in the mountain building history of the Pyrenees. For the main thrust faults in basement, it must be pointed out that direct dating of their activity is rarely available (except the rare age values by Rahl et al., 2011, Waine and McCaig, 1998 and Jolivet et al., 2007, who dated a few fault rocks by Ar and Rb-Sr methods), and the timings are based on correlations with cover thrusts, which are not always straightforward.

All models emphasize that the orogenic development of the Pyrenees was strongly influenced by the pre-orogenic extensional structure. The evolution schemes proposed by 
Mouthereau et al. (2014) and Teixell et al. (2016) incorporate exhumed mantle between the two plates, which was closed during the earliest Pyrenean convergence during the late Cretaceous (since $\sim 84 \mathrm{ma}$ ) by subduction of the mantle lithosphere. The sedimentary cover of the Mesozoic basin was detached and thrust in a pop-up fashion at this stage, while thin basement sheets could be incorporated by shortcut thrusts (e.g. Lakora thrust, North Pyrenean fault-Nogueres thrust according to our interpretation). Collision of the continental margins starts in the ECORS-Pyrenees transect in Campanian times (70-75 Ma) for Mouthereau et al. (2014), on the basis of their thermochronologic results, and in early Eocene times further west (ca. 50-55 ma) for Teixell et al. (2016), as deduced from the onset of exhumation-related cooling in the northwestern Pyrenees at ca. $50 \mathrm{Ma}$ (after data from Vacherat et al., 2014 and Bosch et al., 2016). Vissers and Meijer (2012) added a 300 km-wide exhumed mantle domain to the scheme by Beaumont et al. (2012), initiating convergence at $121 \mathrm{Ma}$ and placing the collision in the ECORS-Pyrenees transect at $83 \mathrm{Ma}$.

By mid-late Eocene times, full collisional deformation was expressed by the thrust accretion of the Iberian crust (e.g. Orri, Rialp, Gavarnie, Guarga thrust sheets, Fig. 16), which produced major crustal thickening, surface uplift and expansive molasse sedimentation in both foreland basins (Beaumont et al., 2000; Vergés et al., 2002; Biteau et al., 2006; Teixell et al., 2016). In parallel, rapid exhumation-related cooling, recorded by thermochronology, took place in the Axial Zone, and continued until the Miocene (Fitzgerald et al., 1999; Sinclair et al., 2005; Jolivet et al., 2007; Metcalf et al., 2009; Bosch et al. 2016; Labaume et al., 2016a,b). Teixell et al. (2016) propose that by late-mid to late Eocene times the stretched and pulled-apart tracts of lower crust (Fig. 12C) of the two plates met, and triggered the limited north-directed subduction or underthrusting of the Iberian lower crust that is imaged in the seismic sections. A fundamental difference between the models of Teixell et al. (2016) (and implicit in the sections of Fig. 16) and those of Beaumont et al. (2000) and Mouthereau et al., (2014) is that the former envisages that the basement thrusts of the southern Pyrenees transfer displacement form the upper thrust of the indented Eurasian wedge (Fig. 16C), whereas for the latter the migrating frontal thrusts of the southern Pyrenees are, at any given time, linked to the main subduction plane. The deformation record in the southern Pyrenees extends to early Miocene times (ca. 20 Ma; Labaume et al., 2016a), slightly after the end of convergence between the Iberian and Eurasian plates deduced from the oceanic 
magnetic anomaly record of the North Atlantic (Chron 6c: 24 Ma; Roest and Srivastava, 1991).

Pedreira et al. (2015) present an evolutionary model for the Cantabrian Mountains (ESCIN-2MARCONI-1 transect) where the main convergence is claimed to start in the mid Eocene (40 $\mathrm{Ma})$, with the onset of crustal wedging duplicating the lower crust under the Cantabrian Mountains. The south-directed indentation of the northern lower crust, overlying a northdirected continental subduction (e.g. Figs. 3D, 12A) represents the sole shortening mechanism of the deep crust in their model for the Cantabrian transect. Shortening was transferred into the upper crust in the form of basement-involved north- and south-directed thrusting in the continental slope and in the thrust front of the Cantabrian Mountains respectively. Like in the Pyrenees, the main uplift and exhumation of the Variscan basement massif occurred in late Eocene to Oligocene times (Pedreira et al. 2015, and references therein). For the pre-orogenic stage, Pedreira et al. (2015) envisage a thinned domain in the proximal Cantabrian margin where the lower crust has been removed (Fig. 14). This domain, which still features middle and upper crust, is bounded by extensional detachments and will localize the wedging and subduction of the continental crust south of the Mesozoic plate boundary (under the Cantabrian Mountains). Although there are no deep seismic reflection images for the Basque-Cantabrian basin, the persistent thick crust found by other methods (Díaz et al., 2016; Palomeras et al., 2017; Ruiz et al., 2017) suggests continuity between the subducted crust of the Cantabrian Mountains and that of the central Pyrenees, although related with different Mesozoic plate configurations.

\section{Conclusions}

Due to good documentation of the surface geology for the onshore areas and to an abundance of deep seismic data, the Pyrenees-Cantabrian Mountains provide a good case for the structural variation of an orogenic belt at a crustal scale. The Pyrenean segment derives from the inversion of a segmented rift basin system with hyperextended margins flanking a central belt of exhumed mantle, while the Cantabrian Mountains represent a shortened continental margin facing oceanic crust, and possibly also exhumed mantle. A series of new interpretative crustal cross-sections updated with the latest data acquired 
illustrate the present-day crustal architecture of the system, emphasizing crustal wedging. These sections incorporate previous knowledge, but also feature a new assessment of thrust relationships in the upper crust and a reinterpretation of the nature and extent of the deep crustal subduction structure.

After initial closure of the exhumed mantle domain in the Late Cretaceous, the Pyrenees raised from the collision of the Iberian and Eurasian margins 10-30 Ma after the initiation of convergence, without previous events of oceanic subduction or Andean-type orogeny. Hence, much of the structure of the Pyrenees is akin to a shortened rift, with pop-up inversion of marginal extensional faults or low-angle detachments. Basement stacking of the Iberian plate resulted in the central high-relief belt of the Axial Zone. Seismic data image a north-directed subduction of a slab of Iberian lower crust to a depth of $60-80 \mathrm{~km}$. This accounts for only a fraction of the total orogenic convergence (>100 km). Moreover, in the west-central Pyrenees the continental subduction has been inferred to occur late in the collisional history.

Reconstructions of the preorogenic basin structure of the Pyrenees published in the recent years coincide in showing narrow continental margins $(<40 \mathrm{~km})$-with a variable symmetry according to the models. Models of margin thinning range from smooth, boudinage-like ductile stretching to high-angle normal faulting with tilted blocks. Smooth margins featured large extensional detachments in the Triassic, so upper-plate pre-rift Mesozoic rocks slid onto the exhumed mantle. These detachments were subsequently reactivated in compression, and along this two-way path they collected fragments of peridotite and diverse crustal rocks.

The central Cantabrian Mountains are also underlain by a north-plunging slab of Iberian lower crust, which is a remarkable geophysical observation as it implies deep-seated shortening of the proximal continental margin of the Bay of Biscay ocean without a clear collision driver. The deep structure of the Cantabrian Mountains is thus similar to the Pyrenees, although according to our interpretation the continental subduction probably did not reach depths beyond $45 \mathrm{~km}$.

To date, the extent of Cretaceous oceanic crust and exhumed mantle in the Bay of Biscay is still uncertain. Although irrefutable evidence is elusive, a limited subduction of the Bay of 
Biscay under the North Iberian margin is here supported, at least west of $4.5^{\circ} \mathrm{W}$. The inferred magnitude of oceanic subduction increases westward to a seismically-imaged depth of 40 $\mathrm{km}$ offshore northern Galicia $\left(9^{\circ} \mathrm{W}\right)$. An exhumed mantle tract may have originally existed between the ancient North Iberian continental margin and the oceanic crust, and could have been subducted at the leading edge of the Bay of Biscay slab.

\section{Acknowledgements}

We thank Ramon Carbonell and Tim Horscroft for the opportunity to write this review paper. Sebastien Chevrot is thanked for providing the unpublished profile in Fig. 7B. We acknowledge the thoughtful revision by two anonymous referees which helped to improve the original manuscript. The latest research activity that has conducted to this work has been supported by projects CGL2014-54180 (MINECO, Spain) and PYRAMID (ANR, France). 


\section{References}

Alonso, J.L., Pulgar, J.A., García-Ramos, J.C., Barba, P., 1996. Tertiary basins and alpine tectonics in the Cantabrian Mountains (NW Spain). In: Friend, P.F., Dabrio, C.J. (Eds.), Tertiary Basins of Spain. The Stratigraphic Record of Crustal Kinematics, Cambridge University Press, New York, pp. 214-227.

Alvarez-Marrón, J., Rubio, E., Torné, M., 1997. Subduction-related structures in the North Iberian Margin. Journal of Geophysical Research 102, B10, 22497-22511.

Ayala, C., Bohoyo, F., Maestro, A., Reguera, M.I., Torne, M., Rubio, F., Fernàndez, M., GarcíaLobón, L., 2016. Updated Bouguer anomalies of the Iberian Peninsula: a new perspective to interpret the regional geology. Journal of Maps 12, 1089-1092

Ayarza, P., Martínez-Catalán, J.R., Gallart, J., Pulgar, J.A., Dañobeitia, J.J., 1998. Estudio Sismico de la Corteza Ibérica Norte 3.3: A seismic image of the Variscan crust in the hinterland of the NW Iberian Massif. Tectonics 17, 171-186.

Ayarza, P., Martínez-Catalán, J.R., Alvarez-Marrón, J., Zeyen, H., Juhlin, C., 2004. Geophysical constraints on the deep structure of a limited ocean-continent subduction zone at the North Iberian Margin. Tectonics 23, doi:10.1029/2002TC001487.

Azambre B., Sagon J.P., Debroas E. J., 1991. Le métamorphisme crétacé du fossé des Baronnies (Hautes Pyrénées, France), témoin des anomanies thermiques de la zone transformante nord pyrénéenne. Comptes Rendus Académie des Sciences de Paris 313, 119-124.

Baby, P., Crouzet, G., Specht, M., Déramond, J., Bilotte, M., Debroas, E.J., 1988. Rôle des paléostructures albo-cénomaniennes dans la géométrie des chevauchements frontaux nord-pyrénéens. Comptes Rendus Académie des Sciences de Paris 306, 307-313.

Barnett-Moore, N., Hosseinpour, M., Maus, S., 2016. Assessing discrepancies between previous plate kinematic models of Mesozoic Iberia and their constraints. Tectonics 35, 1843-1862, doi:10.1002/2015TC004019.

Bayer, B., de Cabissole, B., Casas, A., Corpel, J., Debeglia, N., 1996. Gravimetrie - Anomalie de Bouguer. In: Barnolas, A., Chiron, J.C. (Eds.), Synthèse Géologique et Géophysique des Pyrénées. BRGM-ITGE, Orléans, Planches hors texte, Gph. 4.

Beaumont, C., Muñoz, J.A., Hamilton, J., Fullsack, P., 2000. Factors controlling the Alpine evolution of the Central Pyrenees inferred from a comparison of observations and geodynamical models. Journal of Geophysical Research 105, B4, 8121-8145.

Berástegui, X., Losantos, M., Muñoz, J.A., Puigdefàbregas, C., 1993. Tall geològic del Pirineu central 1:200 000. Servei Geològic de Catalunya, Barcelona, 62 p.

Biteau, J.-J., Le Marrec, A., Le Vot, M., Masset, J.-M., 2006. The Aquitaine Basin. Petroleum Geoscience 12, 247-273.

Boillot, G., Dupeuble, P.A., Malod, J., 1979. Subduction and tectonics on the continental margin off Spain. Marine geology 32, 53-70.

Bonvalot, S., Balmino, G., Briais, A., Kuhn, M., Peyrefitte, A., Vales, N., Biancale, R., Gabalda, G., Moreaux, G., Reinquin, F., Sarrailh, M., 2012. World Gravity Map, 1:50000000. 
Comission for the Geological Map of the World. Eds. BGI-CGMW-CNES-IRD, Paris. (http://bgi.omp.obs-mip.fr/activities/Projects/world_gravity_map_wgm).

Bosch, G., Teixell, A., Jolivet, M., Labaume, P., Stockli, D., Domènech, M., Monié, P., 2016. Record of Eocene-Miocene thrusting in the western Axial Zone and Chaînons Béarnais (west-central Pyrenees) revealed by multi-method thermochronology. Comptes Rendus Geoscience 348, 246-256.

Boillot, G., Malod, J., 1988. The north and north-west Spanish continental margin: A review. Revista de la Sociedad Geológica de España 1, 295-316.

Bronner, A., Sauter, D., Manatschal, G., Péron-Pinvidic G., Munschy, M., 2011. Magmatic breakup as an explanation for magnetic anomalies at magma-poor rifted margins. Nature Geoscience 4, 549-553.

Cadenas, P., Fernández-Viejo, G., 2016. The Asturian Basin within the North Iberian margin (Bay of Biscay): seismic characterisation of its geometry and its Mesozoic and Cenozoic cover. Basin Research 1-21, doi: 10.1111/bre.12187.

Canérot, J., 1988. Manifestations de I'halocinèse dans les Chaînons Béarnais (Zone NordPyrénéenne) au Crétacé inférieur. Comptes Rendus Académie des Sciences de Paris 306, 1099-1102.

Canérot, J., 2017. The pull apart-type Tardets-Mauléon Basin, a key to understand the formation of the Pyrenees. Bulletin Société géologique de France 18, 35, doi: 10.1051/bsgf/2017198.

Casas, A., Kearey, P., Rivero, L., Adam, C.R., 1997. Gravity anomaly map of the Pyrenean region and a comparison of the deep geological structure of the western and eastern Pyrenees. Earth and Planetary Science Letters 150, 65-78.

Chevrot, S., Sylvander, M., Díaz, J., Ruiz, M., Paul, A., PYROPE Working Group, 2015. The Pyrenean architecture as revealed by teleseismic $\mathrm{P}$-to-S converted waves recorded along two dense transects. Geophysical Journal International 200, 1094-1105.

Choukroune, P., ECORS Team, 1989. The ECORS deep seismic profile reflection data and the overall structure of an orogenic belt. Tectonics 8, 23-39.

Choukroune, P., Mattauer, M., 1978. Tectonique des plaques et Pyrénées: sur le fonctionnement de la faille transformante nord-pyrénéenne; comparaison avec les modèles actuels. Bulletin Société géologique de France 5, 689-700.

Clerc, C., Lagabrielle, Y., 2014. Thermal control on the modes of crustal thinning leading to mantle exhumation: Insights from the Cretaceous Pyrenean hot paleomargins. Tectonics 33, 1340-1359, doi:10.1002/2013TC003471.

Clerc, C., Lagabrielle, Y., Labaume, P., Ringenbach, J.-C., Vauchez, A., Nalpas, T., Bousquet, R., Ballard, J.-F., Lahfid, A., Fourcade, S., 2016. Basement-cover decoupling and progressive exhumation of metamorphic sediments at hot rifted margin. Insights from the Northeastern Pyrenean analog. Tectonophysics 686, 82-97.

Clerc, C., Lagabrielle, Y., Neumaier, M., Reynaud, J.Y., de Saint Blanquat, M., 2012.

Exhumation of subcontinental mantle rocks: evidence from ultramafic-bearing clastic 
deposits nearby the Lherz peridotite body, French Pyrenees. Bulletin Société géologique de France 183 (5), 443-459.

Clerc, C., Lahfid, A., Monié, P., Lagabrielle, Y., Chopin, C., Poujol, M., Boulvais, P., Ringenbach, J.-C., Masini, E., de St Blanquat, M., 2015. High-temperature metamorphism during extreme thinning of the continental crust: a reappraisal of the North Pyrenean passive paleomargin. Solid Earth 6, 643-668.

Cochelin, B., Lemirre, B., Denèle, Y., de Saint Blanquat, M., Lahfid, A., Duchêne, S., 2017.

Structural inheritance in the Central Pyrenees: the Variscan to Alpine tectonometamorphic evolution of the Axial Zone. Journal of the Geological Society, London, doi: 10.1144/jgs2017-066.

Corre, B., Lagabrielle, Y., Labaume, P., Fourcade, S., Clerc, C., Ballevre, M., 2016. Deformation associated with mantle exhumation in a distal, hot passive margin environment: New constraints from the Saraillé Massif (Chaînons Béarnais, North-Pyrenean Zone). Comptes Rendus Geoscience 348, 279-289.

Daignières, M., Gallart, J., Banda, E., Hirn, A., 1982. Implications of the seismic structure for the orogenic evolution of the Pyrenean range. Earth and Planetary Science Letters 57, 88-100.

Daignières, M., Séguret, M., Specht, M., ECORS Team, 1994. The Arzacq-Western Pyrenees ECORS Deep Seismic Profile. In: Mascle, A. (Ed.), Hydrocarbon and Petroleum Geology of France, Eur. Ass. Petr. Geosci. Spec. Publ. 4, Springer-Verlag, Berlin, Germany, pp. 199208.

Dauteuil, O., Ricou, L.E., 1989. Une circulation de fluides de haute température à l'origine du métamorphisme crétacé nord-Pyrénéen. Geodinamica Acta 3, 237-250.

Debroas, E.J., 1990. Le flysch noir albo-cénomanien, témoin de la structuration albienne à sénonienne de la zone nordpyrénéenne en Bigorre (Hautes Pyrénées, France). Bulletin Société géologique de France 8(6), 273-285

Debroas, E.J., Canérot, J., Bilotte, M., 2010. Les Brèches d'Urdach, témoins de l'exhumation du manteau pyrénéen dans un escarpement de faille Vraconnien-Cénomanien inférieur (zone nord-pyrénéenne, Pyrénées-Atlantiques, France). Geologie France 2, 53-63.

DeFelipe, I., Pedreira, D., Pulgar, J.A., Iriarte, E., Mendia, M., 2017. Mantle exhumation and metamorphism in the Basque-Cantabrian Basin (N Spain): Stable and clumped isotope analysis in carbonates and comparison with ophicalcites in the North-Pyrenean Zone (Urdach and Lherz). Geochemistry, Geophysics, Geosystems 18, doi:10.1002/2016GC006690.

Déramond, J., Graham, R.H., Hossack, J.R., Baby, P., Crouzet, G., 1985. Nouveau modèle de la chaîne des Pyrénées. Comptes Rendus Académie des Sciences de Paris 301, 1213-1216.

Déramond, J., Baby, P., Specht, M., Crouzet, G., 1988. Géometrie des chevauchements dans la Zone nord-pyrénéenne ariégeoise précisée par le profil ECORS. Bulletin Société géologique France 8, 6, 287-294.

Derégnaucourt, D., Boillot, G., 1982. Structure géologique du golfe de Gascogne. Bulletin Bureau Recherches Géologiques et Minières, 2, 149-178. 
Díaz, J., Gallart, J., Carbonell, R., 2016. Moho topography beneath the Iberian-Western Mediterranean region mapped from controlled-source and natural seismicity surveys. Tectonophysics 692, 74-85.

Díaz, J., Pedreira, D., Ruiz, M., Pulgar, J.A., Gallart, J., 2012. Mapping the indentation between the Iberian and Eurasian plates beneath the Western Pyrenees/Eastern Cantabrian Mountains from receiver function analysis. Tectonophysics 570-571, 114122.

Ducasse, L., Vélasque, P.-C., Muller, J., 1986. Glissement de couverture et panneaux basculés dans la région des Arbailles (Pyrénées occidentales): Un modèle évolutif de la marge nord-ibérique à l'Est de la transformante de Pamplona. Comptes Rendus Académie des Sciences de Paris 303, 1477-1482.

Fernández-Viejo, G., Gallart, J., Pulgar, J.A., Córdoba, D., Dañobeitia, J.J., 2000. Seismic signature of Variscan and Alpine tectonics in NW Iberia: Crustal structure of the Cantabrian Mountains and Duero basin. Journal of Geophysical Research: Solid Earth 105, 3001-3018.

Fernández-Viejo, G., Gallart, J., Pulgar, J.A., Gallastegui, J., Dañobeitia, J.J., Córdoba, D., 1998. Crustal transition between continental and oceanic domains along the North Iberian margin from wide angle seismic and gravity data. Geophysical Research Letters 25 , 4249-4252.

Fernández-Viejo, G., Gallastegui, J., Pulgar, J.A., Gallart, J., 2011. The MARCONI reflection seismic data: A view into the eastern part of the Bay of Biscay. Tectonophysics 508, 3441.

Ferrer, O., Jackson, M.P.A., Roca, E., Rubinat, M., 2012. Evolution of salt structures during extension and inversion of the offshore Parentis Basin (Eastern Bay of Biscay). Geological Society, London, Special Publications 363, 361-380.

Ferrer, O., Roca, E., Benjumea, B., Muñoz, J.A., Ellouz, N., MARCONI Team, 2008. The deep seismic reflection MARCONI-3 profile: Role of extensional Mesozoic structure during the Pyrenean contractional deformation at the eastern part of the Bay of Biscay. Marine and Petroleum Geology 25, 714-730.

Fitzgerald, P.G., Muñoz, J.A., Coney, P.J., Baldwin, S.L., 1999. Asymmetric exhumation across the Pyrenean orogen: implications for the tectonic evolution of a collisional orogen. Earth Planetary Science Letters 173, 157-170.

Ford, M., Hemmer, I., Vacherat, A., Gallagher, K., Christophoul, F., 2016. Retro-wedge foreland basin evolution along the ECORS line, eastern Pyrenees, France. Journal of the Geological Society, London 173, 419-437.

Gallart, J., Banda, E., Daignières, M., 1981. Crustal structure of the Paleozoic Axial Zone of the Pyrenees and transition to the North Pyrenean Zone. Annales de Géophysique 37, 457-480.

Gallastegui, J., 2000. Estructura cortical de la cordillera y margen continental Cantábricos: Perfiles ESCI-N. Trabajos de Geología 22, 3-234. 
Gallastegui, J., Pulgar, J.A., Gallart, J., 2002. Initiation of an active margin at the North Iberian continent-ocean transition. Tectonics 21, 1-10.

Golberg, J.-M., Leyreloup, A.-F., 1990. High temperature-low pressure Cretaceous metamorphism related to crustal thinning (Eastern North Pyrenean Zone, France). Contributions to Mineralogy and Petrology 104, 19-207.

Jammes, S., Huismans, R.S., Muñoz, J.A., 2014. Lateral variation in structural style of mountain building: controls of rheological and rift inheritance. Terra Nova 26, 201-207.

Jammes, S., Manatschal G., Lavier, L., 2010a. Interaction between prerift salt and detachment faulting in hyperextended rift systems: the example of the Parentis and Mauléon basins (Bay of Biscay and western Pyrenees). American Association of Petroleum Geologists Bulletin 94, 957-975.

Jammes, S., Manatschal, G., Lavier, L., Masini, E., 2009. Tectono-sedimentary evolution related to extreme crustal thinning ahead of a propagating ocean: the example of the western Pyrenees. Tectonics 28, TC4012, doi:10.1029/2008TC002406.

Jammes, S., Tiveri, C., Manatschal G., 2010b. 3D architecture of a complex transcurrent rift system: The example of the Bay of Biscay-Western Pyrenees. Tectonophysics 489, 210226.

Johnson, J.A., Hall, C.A., 1989. The structural and sedimentary evolution of the Cretaceous North Pyrenean Basin, southern France. Geological Society of America Bulletin 101, 231 247.

Jolivet, M., Labaume, P., Monié, P., Brunel, M., Arnaud, N., Campani, M., 2007. Thermochronology constraints for the propagation sequence of the south Pyrenean basement thrust system (France-Spain). Tectonics 26, TC5007, doi:10.1029.2006/TC0020280.

Karner, J.D., Watts, A.B., 1983. Gravity anomalies and flexure of the lithosphere at mountain ranges. Journal of Geophysical Research 88, 10449-10477.

Klitgord, K., Schouten, H., 1986. Plate kinematics of the Central Atlantic, Geology of North America 1000, 351-378.

Labaume, P., Meresse, F., Jolivet, M., Teixell, A., Lahfid, A., 2016a. Tectonothermal history of an exhumed thrust-sheet-top basin: An example from the south Pyrerean thrust belt. Tectonics 35, 1280-1313.

Labaume, P., Meresse, F., Jolivet, M., Teixell, A., 2016b. Exhumation sequence of the basement thrust units in the west-central Pyrenees. Constraints from apatite fission track analysis. Geogaceta 60, 11-14.

Labaume, P., Séguret, P., Seyve, C., 1985. Evolution of a turbiditic foreland basin and analogy with an accretionary prism: Example of the Eocene South-Pyrenean basin. Tectonics 4, 661-685.

Labaume, P., Teixell, A., 2014. Diapir rising and squeezing in the north-Pyrenean realm (Chaînons Béarnais): From mid-Cretaceous hyperextension to Pyrenean inversion. Résumés de la 24e Réunion des Sciences de la Terre, Pau, p. 230. 
Lagabrielle, Y., Bodinier, J.L., 2008. Submarine reworking of exhumed subcontinental mantle rocks: Field evidence from the Lherz peridotites, French Pyrenees. Terra Nova 20, 11-21. Lagabrielle, Y., Clerc., C., Vauchez, A., Lahfid, A., Labaume, P., Azambre, B., Fourcade, S., Dautria, J.-M., 2016. Very high geothermal gradient during mantle exhumation recorded in mylonitic marbles and carbonate breccias from a Mesozoic Pyrenean palaeomargin (Lherz area, North Pyrenean Zone, France). Comptes Rendus Geoscience 348, 257-267. Lagabrielle, Y., Labaume, P., de Saint Blanquat, M., 2010. Mantle exhumation, crustal denudation, and gravity tectonics during Cretaceous rifting in the Pyrenean realm (SW Europe): Insights from the geological setting of the Iherzolite bodies. Tectonics 29, TC4012, doi:10.1029/2009TC002588.

Lalaut, P., Sibuet, J.C, Williams, C., 1981. Presentation d'une carte gravimetrique de I'Atlantique nord-est. Comptes Rendus Académie des Sciences de Paris 300, 145-149. Laumonier, B., 2015. Les Pyrénées alpines sud-orientales (France, Espagne) - essai de synthèse. Revue de Géologie pyrénéene 2015, 2, 1, 44 p.

Ledo, J.J., Ayala, C., Pous, J., Queralt, P., Marcuello, A., Muñoz, J.A. 2000. New geophysical constraints on the deep structure of the Pyrenees. Geophysical Research Letters 27, 1037-1040.

Le Pichon, X., Sibuet, J.C., 1971. Western extension of boundary between European and Iberian plates during the Pyrenean orogeny. Earth and Planetary Science Letters 12, 8388.

López-Mir, B., Muñoz, J.A., García-Senz, J., 2014. Extensional salt tectonics in the partially inverted Cotiella post-rift basin (south-central Pyrenees): structure and evolution, International Journal of Earth Sciences 104, 419-434.

Martín-González, F., Heredia, N. 2011. Geometry, structures and evolution of the western termination of the Alpine-Pyrenean Orogen reliefs (NW Iberian Peninsula). Journal of Iberian Geology 37, 103-120.

Martínez-Peña, M.B., Casas-Sainz, A.M., 2003. Cretaceous-Tertiary tectonic inversion of the Cotiella Basin (southern Pyrenees, Spain). International Journal of Earth Sciences 92, 99113.

Martínez Poyatos, D., Carbonell, R. Palomeras, I., Simancas, F., Ayarza, P., Martí, D., Azor, A., Jabaloy, A., González-Cuadra, P., Tejero, R., Martín-Parra, L.M., Matas, J., González Lodeiro, F., Pérez-Estaún, A., García Lobón, J.L., Mansilla, L., 2012. Imaging the crustal structure of the Central Iberian Zone (Variscan Belt): The ALCUDIA deep seismic reflection transect. Tectonics 31, TC3017, doi:10.1029/2011TC002995.

Masini, E., Manatschal, G., Tugend, J., Mohn, G., Flament, J.-M., 2014. The tectonosedimentary evolution of a hyper-extended rift basin: The example of the ArzacqMauléon rift system (Western Pyrenees, SW France). International Journal of Earth Sciences 103, 1569-1596.

Metcalf, J.R., Fitzgerald, P.G., Baldwin, S.L., Muñoz, J.A., 2009. Thermochronology of a convergent orogen: Constraints on the timing of thrust faulting and subsequent 
exhumation of the Maladeta Pluton in the Central Pyrenean Axial Zone. Earth and Planetary Science Letters 287, 488-503.

Montadert, L., de Charpal, O., Roberts, D.G., Guennock, P., Sibuet, J.C., 1979. Northeast Atlantic passive margins: rifting and subsidence processes. American geophysical Union, Maurice Ewing series 3, 154-186.

Mouthereau, F., Filleaudeau, P.-Y., Vacherat, A., Pik, R., Lacombe, O., Fellin, M.G., Castelltort, S., Christophoul, F., Masini, E., 2014. Placing limits to shortening evolution in the Pyrenees: Role of margin architecture and implications for the Iberia/Europe convergence. Tectonics 33, 2283-2314. doi:10.1002/2014TC003663.

Muñoz, J.A., 1992, Evolution of a continental collision belt: ECORS-Pyrenees crustal balanced cross-section. In: McClay, K.R. (Ed.), Thrust Tectonics, Chapman and Hall, London, pp. 235-246.

Muñoz, J.A., 2002. The Pyrenees. In: Gibbons, W., Moreno, T. (Eds.), The Geology of Spain. The Geological Society, London, pp. 370-385.

Muñoz, J.A., Beamud, E., Fernández, O., Arbués, P., Dinarès-Turell, J., Poblet, J., 2013. The Ainsa fold and thrust oblique zone of the central Pyrenees: Kinematics of a curved contractional system from paleomagnetic and structural data. Tectonics 32, 1142-1175. doi:10.1002/tect.20070.

Nirrengarten, M., Manatschal, G., Tugend, J., Kusznir, N.J., Sauter, D., 2017. Nature and origin of the J-magnetic anomaly offshore Iberia-Newfoundland: implications for plate reconstructions. Terra Nova 29, 20-28.

Olivet, J.L., 1996. La cinématique de la plaque Ibérique. Bull. Centr. Rech. Explor.-Prod. Elf Aquitaine 20, 131-195.

Palomeras, I., Villaseñor, A., Thurner, S., Levander, A., Gallart, J., Harnafi, M., 2017. Lithospheric structure of Iberia and Morocco using finite-frequency Rayleigh wave tomography form earthquakes and seismic ambient noise. Geochemistry, Geophysics, Geosystems 18, doi:10.1002/2016GC006657.

Pedreira, D., Afonso, J.C., Pulgar, J.A., Gallastegui, J., Carballo, A., Fernàndez, M., GarciaCastellanos, D., Jiménez-Munt, I., Semprich, J., García-Moreno, O., 2015. Geophysicalpetrological modeling of the lithosphere beneath the Cantabrian Mountains and the North-Iberian margin: geodynamic implications. Lithos 230, 46-68.

Pedreira, D., Pulgar, J., Gallart, J., Díaz, J., 2003. Seismic evidence of Alpine crustal thickening and wedging from the western Pyrenees to the Cantabrian Mountains (north Iberia). Journal of Geophysical Research 108, B4, 2204, doi:10.1029/2001JB001667.

Pedreira, D., J. A. Pulgar, J. Gallart, M. Torné, 2007. Three-dimensional gravity and magnetic modeling of crustal indentation and wedging in the western Pyrenees- Cantabrian Mountains. Journal of Geophysical Research 112, B12405, doi:10.1029/2007JB005021.

Pinet, B., Montadert, L., Curnelle, R., Cazes, M., Marillier, F., Rolet, J., Tomassino, A., Galdeano, A., Patriat, Ph., Brunet, M.F., Olivet, J.L., Schaming, M., Lefort, J.P., Arrieta, A., Riaza, C., 1987. Crustal thinning of the Aquitaine shelf, Bay of Biscay, from deep seismic data. Nature 325, 513-516. 
Pous, J., J.A. Muñoz, J. Ledo, and M. Liesa, 1995. Partial melting of the subducted continental lower crust in the Pyrenees, J. Geol. Soc. London 152, 217-220.

Pulgar, J.A., Gallart, J., Fernández-Viejo, G., Pérez-Estaún, A., Alvarez-Marrón, J., ESCIN Group, 1996. Seismic image of the Cantabrian Mountains in the western extension of the Pyrenees from integrated ESCIN reflection and refraction data. Tectonophysics 264, 1-19.

Quintana, L., Pulgar, J.A., Alonso, J.L., 2016. Displacement transfer from borders to interior of a plate: a crustal transect of Iberia. Tectonophysics 663, 378-398.

Rahl, J.M., Haines, S.H., van der Pluijm, B.A. 2011. Links between orogenic wedge deformation and erosional exhumation: evidence from illite age analysis of faut rock and detrital thermochronology of syn-tectonic conglomerates in the Spanish Pyrenees. Earth and Planetary Science Letters 307, 180-190.

Roca, E., Muñoz, J.A., Ferrer, O., Ellouz, N., 2011. The role of the Bay of Biscay Mesozoic extensional structure in the configuration of the Pyrenean orogen: Constraints from the MARCONI deep seismic reflection survey. Tectonics 30, TC2001.

doi:10.1029/2010TC002735.

Roest, W.R., Srivastava, S.P., 1991. Kinematics of the plate boundaries between Eurasia, Iberia, and Africa in the North Atlantic from the Late Cretaceous to the present. Geology 19, 613-616.

Roure, F., Choukroune, P., Berástegui, X., Muñoz, J.A., Villien, P., Matheron, P., Bareyt, M., Séguret, M., Camara, P., Déramond, J., 1989. ECORS Deep Seismic data and data and balanced cross-sections: Geometric constraints on the evolution of the Pyrenees. Tectonics 8, 41-50.

Rudnick, R.L., Fountain, D.M., 1995. Nature and composition of the continental crust; a lower crustal perspective. Reviews of Geophysics 33, 267-309.

Ruiz, M., 2007., Caracterització estructural i sismotectònica de la litosfera en el domini Pirenaico-Cantàbric a partir de mètodes de sísmica activa i passiva. PhD Thesis, Univ. de Barcelona, $354 \mathrm{p}$.

Ruiz, M., Díaz, J., Pedreira, D., Gallart, J., Pulgar, J.A., 2017. Crustal structure of the North Iberian continental margin from seismic refraction/wide-angle reflection profiles. Tectonophysics 717, 65-82.

Saint Blanquat, M. de, Brunel, M., Mattauer, M., 1986. Les zones de cisaillement du massif Nord-pyrénéen du Saint-Barthélemy témoins probables de l'extension crustale d'âge crétacé. Comptes Rendus Académie des Sciences de Paris, Série II, 303, 1339-1344.

Saint Blanquat, M. de, Bajolet, F., Grand'Homme, A., Proietti, A., Zanti, M., Boutin, A., Clerc, C., Lagabrielle, Y., Labaume, P., 2016. Cretaceous mantle exhumation in the central Pyrenees: new constraints from the peridotites in eastern Ariège (North Pyrenean zone, France). Comptes Rendus Geoscience 348, 268-278.

Santolaria, P., Casas-Sainz, A.M., Soto, R., Pinto, V., Casas, A., 2014. The Naval diapir (southern Pyrenees): Geometry of a salt wall associated with thrusting at an oblique ramp. Tectonophysics 637, 30-44. 
Saura, E., Ardévol, LI., Teixell, A., Vergés, J., 2016. Rising and falling diapirs, shifting depocenters and flap overturning in the Cretaceous Sopeira and Sant Gervàs subbasins (Ribagorça basin, Pyrenees). Tectonics 35, 638-662.

Saura, E., Teixell, A., 2006. Inversion of small basins: effects on structural variations at the leading edge of the Axial Zone antiformal stack (Southern Pyrenees, Spain). Journal of Structural Geology 28, 1909-1920.

Séguret, M., 1972. Etude tectonique des nappes et séries décollées de la partie centrale du versant sud des Pyrénées. Caractère synsédimentaire, rôle de la compression et de la gravité. PhD thesis, Univ. de Montpellier, $150 \mathrm{p}$.

Séguret, M., Daignières, M., 1986. Crustal scale balanced cross-sections of the Pyrenees; discussion. Tectonophysics 129, 303-318.

Sibuet, J.C., Srivastava, S.P., Spakman, W., 2004. Pyrenean orogeny and plate kinematics. Journal of Geophysical Research 109, B08104, doi:10.1029/2003JB002514.

Sinclair, H.D., Gibson, M., Naylor, M., Morris, R.G., 2005. Asymmetric growth of the Pyrenees revealed through measurement and modeling of orogenic fluxes. American Journal of Science 305,369-406.

Soler, R., López-Vilchez, J., Riaza, C., 1981. Petroleum Geology of the Bay of Biscay. In: Illing, L.V., Hobson, G.D. (Eds.), Petroleum geology of the continental shelf of North-West Europe, The Institute of Petroleum, London, pp. 474-482.

Soler, D., Teixell, A., García-Sansegundo, J. 1998. Amortissement latéral du chevauchement de Gavarnie et sa relation avec les unités sud-pyrénéenes. Comptes Rendus Académie des Sciences de Paris 327, 699-704.

Souquet, P., Mediavilla, F., 1976. Nouvelle hypothèse sur la formation des Pyrénées, Comptes Rendus Académie des Sciences de Paris 282, 2139-2142.

Souriau, A., Granet, M., 1995. A tomographic study of the lithosphere beneath the Pyrenees from local and teleseismic data. Journal of Geophysical Research 100, 18117-18134.

Srivastava, S.P., Roest, W.R., Kovacs, L.C., Oakey, G., Lévesque S., Verhoef J., Macnab, R., 1990. Motion of Iberia since the Late Jurassic: Results from detailed aeromagnetic measurements in the Newfoundland Basin. Tectonophysics 184, 229-260.

Srivastava, S.P., Sibuet, J.-C., Cande, S., Roest, W.R., Reid, I.D., 2000. Magnetic evidence for slow seafloor spreading during the formation of the Newfoundland and Iberian margins. Earth and Planetary Science Letters 182, 61-76.

Teixell, A., 1996. The Ansó transect of the southern Pyrenees: basement and cover thrust geometries. Journal of the Geological Society, London 153, 301-310.

Teixell, A., 1998. Crustal structure and orogenic material budget in the west-central Pyrenees. Tectonics 17, 395-406.

Teixell, A., 2004. Estructura cortical de la Cordillera Pirenaica. In: Vera, J.A. (Ed.), Geologia de España. Sociedad Geológica de España-Instituto Geológico y Minero de España, Madrid, pp. 320-321. 
Teixell, A., Labaume, P., Lagabrielle, Y., 2016. The crustal evolution of the west-central Pyrenees revisited: inferences from a new kinematic scenario. Comptes Rendus Geoscience 348, 257-267.

Teixell, A., Muñoz, J.A., 2000. Evolución tectono-sedimentaria del Pirineo meridional durante el Terciario: una síntesis basada en la transversal del río Noguera Ribagorçana. Revista de la Sociedad Geológica de España 13, 295-316.

Téllez, J., Matías, L.M., Córdoba, D., Mendes-Victor, L.A., 1993. Structure of the crust in the schistose domain of Galicia-Tras-Os-Montes (NW Iberian Peninsula). Tectonophysics 221, 81-94.

Thybo, H., Artemieva, I.M., 2013. Moho and magmatic underplating in continental lithosphere. Tectonophysics 609, 605-619.

Torné, M., de Cabissole, B., Bayer, R., Casas, A., Daignières, M., Rivero, A., 1989. Gravity constraints on the deep structure of the Pyrenean belt along the ECORS profile. Tectonophysics 165, 105-116.

Torné, M., Fernàndez, M., Vergés, J., Ayala, C., Salas, M.C., Jimenez-Munt, Y., Buffet, G.G., Díaz, J., 2015. Crust and mantle lithospheric structure of the Iberian Peninsula deduced from potential field modeling and thermal analysis. Tectonophysics 663, 419-433.

Tugend, J., Manatschal, G., Kusznir, N.J., Masini, E. Mohn, G., Thinon, I., 2014. Formation and deformation of hyperextended rift systems: Insights from rift domain mapping in the Bay of Biscay-Pyrenees. Tectonics 33, doi:10.1002/2014TC003529.

Vacher, P., Souriau, A., 2001. A 3-D model of the Pyrenean deep structure based on gravity modelling, seismic images, and petrological constraints. Geophysical Journal International 145, 460-470.

Vacherat, A., Mouthereau, F., Pik, R., Bernet, M., Gautheron, C., Masini, E., Le Pourhiet, L., Tibaric, B., Lahfid. A., 2014. Thermal imprint of rift-related processes in orogens as recorded in the Pyrenees. Earth and Planetary Science Letters 408, 296-306.

Vissers, R.L.M., Meijer, P., 2012. Mesozoic rotation of Iberia: Subduction in the Pyrenees? Earth Science Reviews 110, 93-110.

Vergés, J. 1993. Estudi geològic del vessant sud del Pirineu oriental i central. Evolució cinemàtica en 3D. PhD Thesis, Univ. de Barcelona, 192 p.

Vergés, J., Fernàndez, M., Martínez, A., 2002. The Pyrenean orogen: pre-, syn- and postcollisional evolution. Journal of the Virtual Explorer 8, 57-76.

Vergés, J., García-Senz, J., 2001. Mesozoic evolution and Cainozoic inversion of the Pyrenean Rift. In: Ziegler, P.A., et al. (Eds.), Peri-Tethys Memoir 6, Memoires Muséum National d'Histoire Naturelle, 186, 187-212.

Vergés, J., Millán, H., Roca, E., Muñoz, J.A., Marzo, M., Cirés, J., Den Bezemer, T., Zoetemeijer, R., Cloetingh, S., 1995. Eastern Pyrenees and related foreland basins: Pre-, syn- and post-collisional crustal-scale cross-sections. Marine and Petroleum Geology 12, 893-915.

Vielzeuf, D., Kornprobst, J., 1984. Crustal splitting and the emplacement of Pyrenean Iherzolites and granulites. Earth Planetary Science Letters 67, 87-96. 
Wang, Y., Chevrot, S., Monteiller, V., Komatitsch,D., Mouthereau, F., Manatschal, G., Sylvander, M., Díaz, J., Ruiz, M., Grimaud, F., Benahmed, S., Pauchet, H., Martin, R., 2016. The deep roots of the western Pyrenees revealed by full waveform inversion of teleseismic P waves. Geology 44, 475-478.

Wayne, D.M., McCaig, A.M., 1998. Dating fluid flow in shear zones: Rb-Sr and U-Pb studies of syntectonic veins in the Néouvielle massif, Pyrenees. In: Parnell, J. (Ed.), Dating and Duration of Fluid Flow and Fluid-Rock Interaction, Geological Society, London, Special Publications 144, 129-135.

Williams, C.A., 1975. Sea-floor spreading in the Bay of Biscay and its relationship to the North Atlantic. Earth and Planetary Science Letters 24, 440-456. 


\section{Figure captions (Teixell et al.)}

Fig. 1. Tectonic map of the Pyrenean-Cantabrian orogenic belt indicating the cross-section lines and the main deep seismic profiles discussed in this work. Brown: reflection profiles; blue: receiver function profiles; M0, A34N, A34S: labelled oceanic magnetic anomalies in the Bay of Biscay abyssal plain; VA: V-shaped magnetic anomaly of the eastern Bay of Biscay (traced after Sibuet et al., 2004); NIP: North Iberian thrust prism; OS: Ortegal spur; DB: Le Danois bank; TC, SC: Torrelavega and Santander canyons (transfer zone); FC: Cap Ferret canyon; PB: Parentis basin; LH: Landes high; AM : Asturian massif; BCB: Basque-Cantabrian basin; CV: Cinco Villas massif; PF: Pamplona fault (transfer zone); MB: Mauléon basin; LT: Lakora thrust; GT: Gavarnie thrust; AZ: Axial Zone; NPF: North Pyrenean fault; 3S: Trois-Seigneurs massif.

Fig. 2. Simplified line-drawing sketches of the ECORS deep seismic reflection profiles across the Pyrenees (unmigrated; recorded time for the southern part of the ECORS-Pyrenees and for the ECORS-Arzacq profile: $20 \mathrm{~s}$; recorded time for the northern part of the ECORS-Pyrenees profile: $25 \mathrm{~s}$ ). Highlighted are the main reflective units distinguished, the upper crust sedimentary cover and the reflective lower crust. SPFT: South Pyrenean frontal thrust; NPFT: North Pyrenean frontal thrust; NPF: North Pyrenean fault.

Fig. 3. Crustal-scale geologic cross-sections of the Pyrenees that derived from the ECORS and ESCIN seismic programs (after Roure et al., 1989; Muñoz, 1992; Teixell, 1998; Pulgar et al., 1996; Gallastegui 2000, redrawn from Teixell, 2004). SPFT: South Pyrenean frontal thrust; NPFT: North Pyrenean frontal thrust; NPF: North Pyrenean fault.

Fig. 4. Seismic profiles of the Cantabrian Mountains and the North Iberian margin-Bay of Biscay that surveyed the deep crust and Moho discontinuity. (A) ESCIN-2 reflection profile across the Cantabrian Mountains (after Pulgar et al., 1996). $\mathrm{H}$ marks the reflectivity at the base of the lower crust; I is interpreted as overthrust lower crust; D-D' to G-G' mark interpreted thrust faults, whereas $A$ and $B$ mark the reflective Mesozoic and Tertiary sedimentary rocks of the Duero basin, and $C$ the base of the Paleozoic sequence of the Cantabrian mountains. (B) Velocity model after ESCIN-4 wide-angle data and its southern continuation onshore (reproduced from Pedreira et al. 2015 after FernándezViejo et al., 1998). See Fig. 1 for location.

Fig. 5. Moho depth map of the Pyrenean-Cantabrian belt obtained from the interpolation of deep seismic profiling and receiver function estimations, completed with modeling in areas not sampled by seismic experiments (after Díaz et al., 2016).

Fig. 6. Free air gravity anomaly map of the Pyrenean-Cantabrian belt and the Bay of Biscay, showing the gravity minima at the foot of the North Iberian margin between $4-9^{\circ} \mathrm{W}$ attributable to the 
subduction of the oceanic crust of the bay. Gravity database from Bonvalot et al. (2012); trace of main tectonic structures offshore as in Fig. 1.

Fig. 7. Stack profiles of receiver functions for the PYROPE transects across the central Pyrenees. (A) PYROPE E; (B) PYROPE Centre; (C) PYROPE W (see location in Fig. 1) (A and C reproduced from Chevrot et al., 2015, B by personal communication by S. Chevrot). Black and gray dashed lines in A and $C$ indicate the positive and negative polarity interfaces attributed by Chevrot et al. (2015) to the Moho discontinuity and the major thrust/subduction zones, respectively. The same features are represented for profile $B$. The position of the inferred Moho from the ECORS-Pyrenees and ECORSArzacq reflection profiles is indicated by blue dashes. SPFT: South Pyrenean frontal thrust; NPFT: North Pyrenean frontal thrust; NPF: North Pyrenean fault; SPCU: northern border of South Pyrenean sedimentary cover units.

Fig. 8. Bouguer gravity anomaly map of the Pyrenees and Cantabrian Mountains. Red traces indicate the main boundary structures. Thick dashed lines indicate the traces of the seismic profiles labelled in Fig. 1. La: Labourd gravity anomaly; Lo: Lourdes gravity anomaly; SG: Saint-Gaudens gravity anomaly. Gravity database from Ayala et al. (2016).

Fig. 9. Interpreted geologic cross-section following the PYROPE $W$ transect after Vs and Vp fullwaveform inversion modeling (from Wang et al., 2016) (see location of PYROPE W in Fig. 1).

Fig. 10. Window of the southern part of the ECORS-Arzacq seismic reflection profile (unmigrated), showing weak horizontal reflections at around $10 \mathrm{sec}$. (arrows) until the southern extremity of the profile (see location in Fig. 1). These reflections are attributed to the Eurasian lower crust and Moho.

Fig. 11. Metamorphic map of the northern Pyrenees showing maximum paleotemperatures attained during the Cretaceous extensional episode (after Clerc et al. 2015).

Fig. 12. End-member models for the Cretaceous continental margins of the Pyrenees, before the onset of plate convergence around $84 \mathrm{ma}$. (A) Schematic reconstruction of the continental margins of the Mauléon basin (western North Pyrenean Zone) at Cenomanian-Turonian times following a tiltedblock model of extension (redrawn after Masini et al. 2014). (B) Schematic reconstruction of the Eastern Pyrenees basins at Cenomanian-Coniacian times illustrating the hot-paleomargin model (redrawn after Clerc et al., 2015). Note the crustal boudin later to become a North Pyrenean basement massif (i.e. the Agly massif). (C) Restored cross-section of the Chaînons Béarnais-Jaca transect (Fig. 16C) showing the detailed geometrical reconstruction of the Cretaceous continental margins with smooth tops dipping basinward. The width of the exhumed mantle domain corresponds 
to the restored width of the Iherzolite outcrops of the Sarrance and Mail Arrouy Chaînons (modified after Teixell et al., 2016). The lower crust is interpreted to have been removed from the Iberian margin, giving a minimum stretching of ca. $65 \mathrm{~km}$ ( $\beta>2$ in the basin extent). LF: Licq fault; LkT: trace of future Lakora shortcut thrust carrying the Iguntze-Mendibelza thin basement unit.

Fig. 13. Interpreted ECORS-Biscay seismic reflection profile across the Parentis basin (from Jammes et al., 2010b) (location in Fig. 1). The thinned structure of the crust in this profile may be taken as an analog for the restored smooth continental margins of the Chaînons Béarnais segment of the North Pyrenean Zone (Fig. 12C), in this case without a central domain of mantle exhumation. Note that crustal thinning is accompanied by detachment and extensional denudation of the sedimentary cover in the southern side of the Parentis basin. Red Arrow indicates a late fault type that in the Pyrenees may lead to shortcut thrusting (e.g. Iguntze-Mendibelza massifs, Licq fault in Figs. $12 \mathrm{C}$ and 16C). T: Triassic; J: Jurassic; $\mathrm{Ci}$ and Cs: Lower and Upper Cretaceous; T: Tertiary.

Fig. 14. Pedreira et al. (2015) reconstruction of the continental margin and basins for the Cantabrian Mountains and the Bay of Biscay at Early Eocene times, previous to the onset of main convergence (ESCIN-2-MARCONI-1 transect, see location in Fig. 1). The nature of the basement of the Bay of Biscay abyssal plain is uncertain, having been attributed to underplated magmatic rocks, transitional or oceanic crust, or exhumed mantle rocks (Roca et al., 2011, Tugend et al.2014; Pedreira et al., 2015 and references therein). The north-dipping extensional fault system of the continental slope is also speculative, as it is interpreted for the present-day to form a south-dipping thrust system (e.g. Fig. 3D), of unresolved internal structure (Pedreira et al., 2015).

Fig. 15. Reconstruction of the Iberian plate with respect to Eurasia at chron M0 times (Aptian, 121$125 \mathrm{Ma}$ ) according to different models (from Barnett-Moore et al., 2016). These models differ in the amount of rotation and lateral drift of Iberia according to contrasting interpretations of the position of the continent-ocean transitions and the significance of the J magnetic anomalies in the North Atlantic. Brown shading shows the position of Iberia at C34 (early Campanian, 83-84 Ma), near the onset of Pyrenean convergence, for which there are less discrepancies.

Fig. 16. New geological cross-sections at the crustal scale for the Pyrenees (see also Fig. 1 for location). (A) New interpretation of a section following the ECORS-Pyrenees and PYROPE E profiles (geology modified from Baby et al. 1988; Muñoz, 1992; Lagabrielle et al., 2010). The structure above the Axial Zone is interpretative and differs from previous models (see text for discussion). (B) The Nestes-Aínsa section following the PYROPE Centre profile (geology after Martínez-Peña and CasasSainz, 2003; Lopez-Mir et al., 2014 and own data) (C) Chaînons Béarnais-Jaca section modified after Teixell et al. (2016). SPFT: South Pyrenean frontal thrust; NPFT: North Pyrenean frontal thrust; NPF: North Pyrenean fault; IMZ: Internal metamorphic zone in (B); EMZ: External metamorphic zone; LF: Licq fault in (C). 
Fig. 17. New geological cross-sections at the crustal scale for the Cantabrian Mountains, North Iberian margin and Bay of Biscay (see Figs. 1 or 16 for location). (A) New interpretation of a section following the trace of the ESCIN-2 and MARCONI-1 reflection profiles. This section benefits from further geophysical interpretation shown in Figs. 18 and 19 (geology modified from Gallastegui, 2000; Cadenas and Fernández-Viejo, 2016 and Roca et al., 2011). M: Moho discontinuity. The existence of oceanic crust in this transect is interpretative (see text for discussion). The striped area in the northern thrust prism represents high density lower crust or mantle rocks deduced by gravity data (Fig. 19A). (B) Cartoon of the structure offshore Galicia following the IAM-12 profile. The IAM-12 line was published in Alvarez-Marrón et al. (1997) and Tugend et al. (2014), and does not image the continental Moho nor the oceanic slab, although it shows the geometry of the North Iberian thrust prism and basins on top of the oceanic and continental plates. The ESCIN-3 line intersects the IAM-12 at high angle (Fig. 1) and shows at flat continental Moho of the upper plate at $9 \mathrm{~s}$ TWT and inclined, out-of-the-plane reflections at mantle depths ca. 12-14 sec TWT that were modeled by Ayarza et al. (2004) as the top of a subducted slab of the Bay of Biscay crust. Internal features within the continental basement necessary to fit the free-air gravity anomaly in Fig. 19 are not represented.

Fig. 18. Migrated ESCIN-2 seismic reflection profile across the Cantabrian Mountains and Duero basin (see location in Fig. 1). CDP interval: $30 \mathrm{~m}$, migration velocity: $4000 \mathrm{~m} / \mathrm{s}$. Further processing parameters are given in Table 1. M: Moho discontinuity.

Fig. 19. (A) Free-air gravity model of a section line following the ESCIN-2 and MARCONI-1 profiles. The ESCIN-2 profile is reinterpreted as to account for subduction of lower crust only. (B) Free-air gravity model of a section line following the IAM-12 profile (see location in Fig. 1). CL: shoreline. Gravity models follow the seismic profiles and do not cut the gravity anomalies along their maxima, which implies that, in some cases, gravity values respond to bodies that are located out of line according the profile but that need to be included in the models, even though they might not be located along the section and thus, not seen in the seismic profile. This is particularly striking along the model in $(A)$, where a relative maximum appears in the minimum corresponding to the Asturian basin. This maximum increases to the $\mathrm{W}$ of the section and probably has its source off the model.

Fig. 20. Sketch restoration to initial Late Cretaceous times of section in Fig. $16 \mathrm{~A}$ along the ECORSPyrenees and PYROPE E profiles. Names in black refer to future Pyrenean thrusts or tectonic units, whereas those in green refer to lower Cretaceous basins. The Nogueres thrust sheet is envisaged as a thin shortcut thrust unit of an upper Cretaceous basement high, originally on top of the Axial Zone. The basal thrust (dashed) links to the inversion of the Aulus basin, floored by an exhumed mantle tract of unknown width (see text for discussion). Esbints: position of upper Cretaceous flysch 
outcrops at Esbints, northern Axial zone; NPF: North Pyrenean fault. 3Ss: Trois-Seigneurs massif; NPFT: North Pyrenean frontal thrust.

Table 1. Processing sequence for the migrated vertical incidence seismic profile ESCIN-2 (Fig. 13), as specified by the contractor (CGG). 
Table 1

1. Transfer from demultiplexed SEG-B format to CGG format

2. Amplitude recovery $4 \mathrm{~T} / 1000$

3. Dynamic trace equalization. Window operator length: $0-25 . s, 5.0 \mathrm{~s}$

4. Slalom line Common Mid-Point gather, CMP interval $=30 \mathrm{~m}$.

5. Trace edit

6. Anti-alias filter

7. Resample to $8 \mathrm{~ms}$

8. Elevation replacement statics

9. NMO correction and muting of the velocity field from constant velocity stacks

10. Surface consistent residual statics

pass 1: long wavelength corrections

11. Stack

pass 2: long wavelength corrections

12. High pass filter $(8,10 \mathrm{~Hz})$

13. $\mathrm{F} / \mathrm{K}$ domain migration $(\mathrm{V}=4000 \mathrm{~m} / \mathrm{s})$

14. Time variant trace mix window weighting 0 -3.0s, $1: 4: 1$

6-20.s 1:2:8:2:1

15. Time variant band-pass filter $10 \mathrm{~Hz}-50 \mathrm{~Hz}(0-5 \mathrm{~s}), 8 \mathrm{~Hz}-30 \mathrm{~Hz}(10-20 \mathrm{~s})$

16. F/X random noise attenuation time operator 


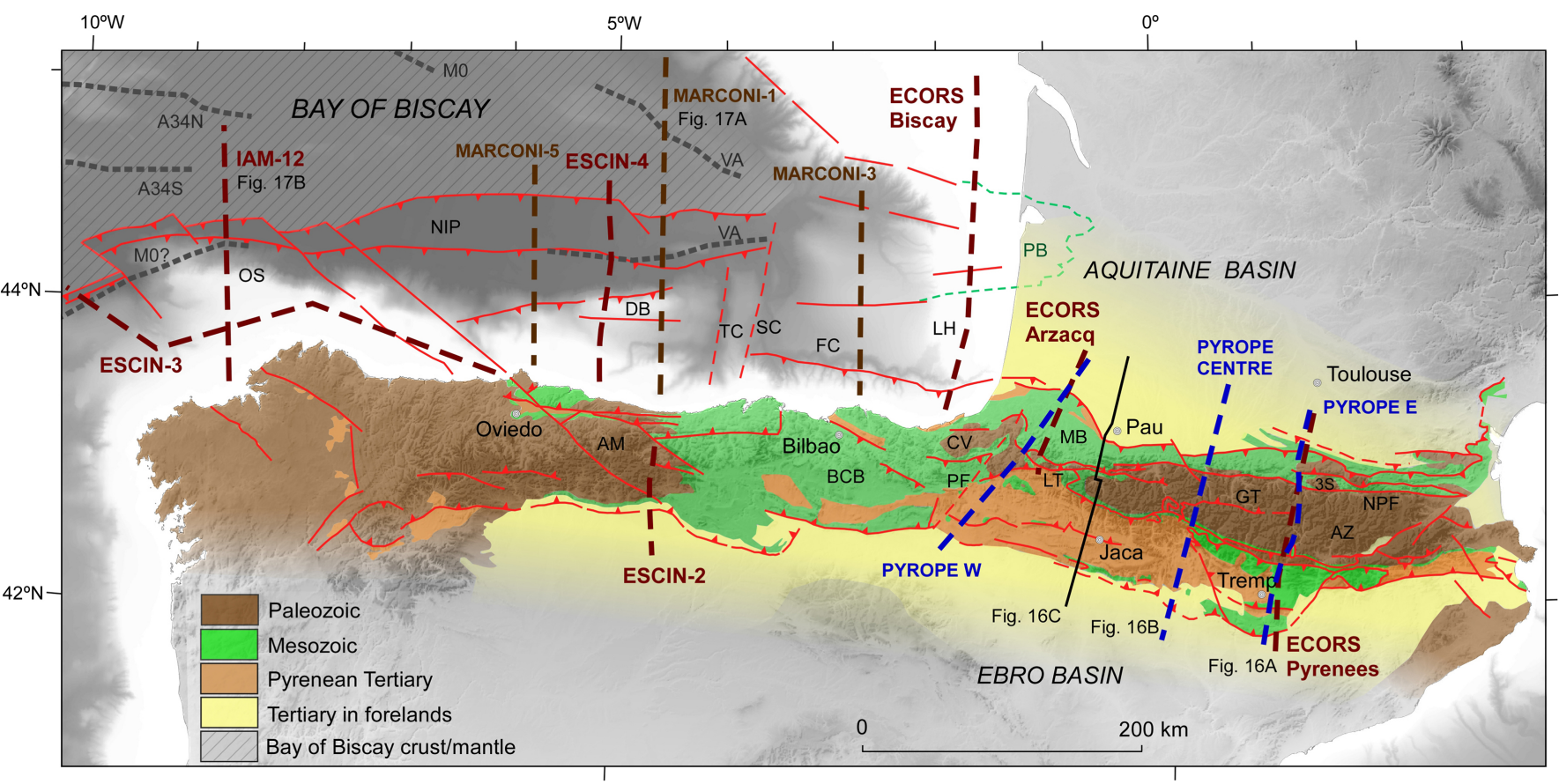

Figure 1 


\section{ECORS-PYRENEES PROFILE}

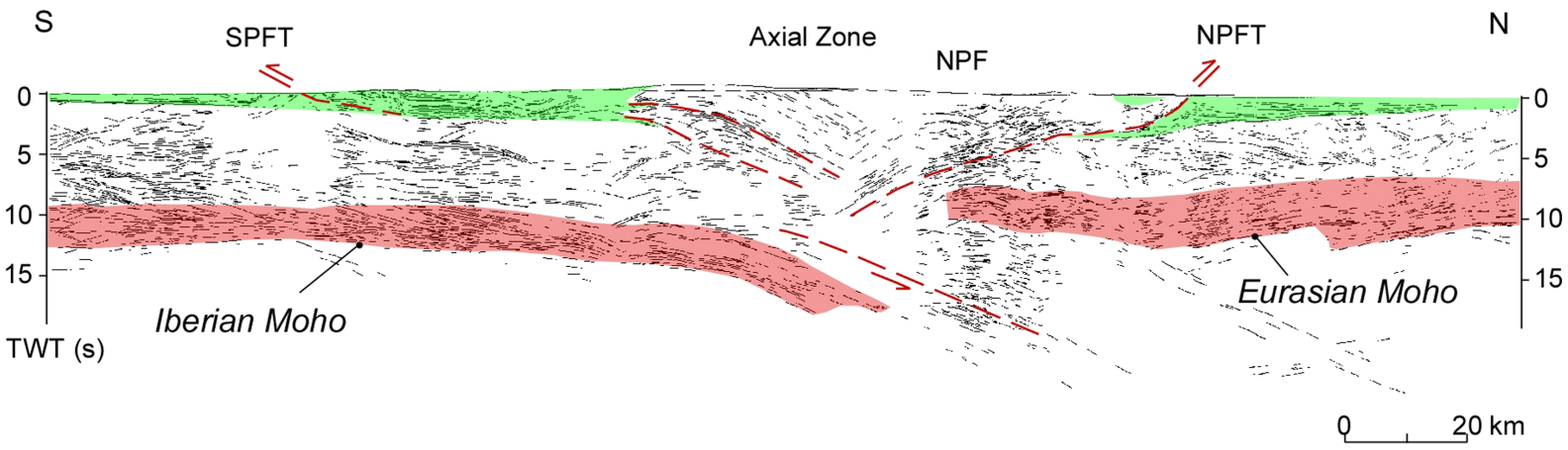

Meso-Cenozoic sediments

Lower crust

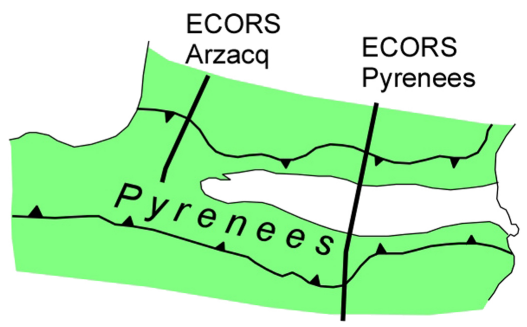

\section{ECORS-ARZACQ PROFILE}

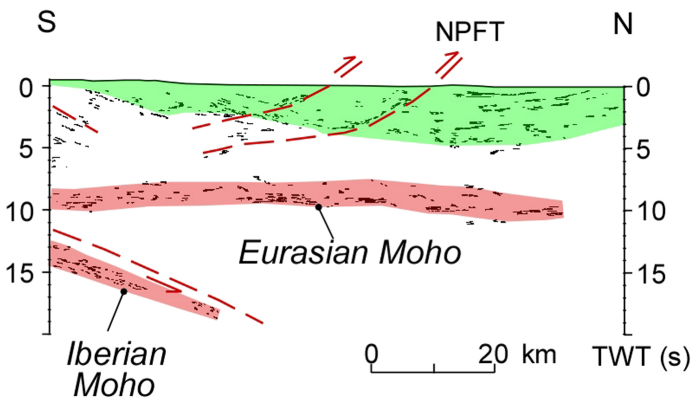

Figure 2 
A) ECORS-Pyrenees (Roure et al. 1989)

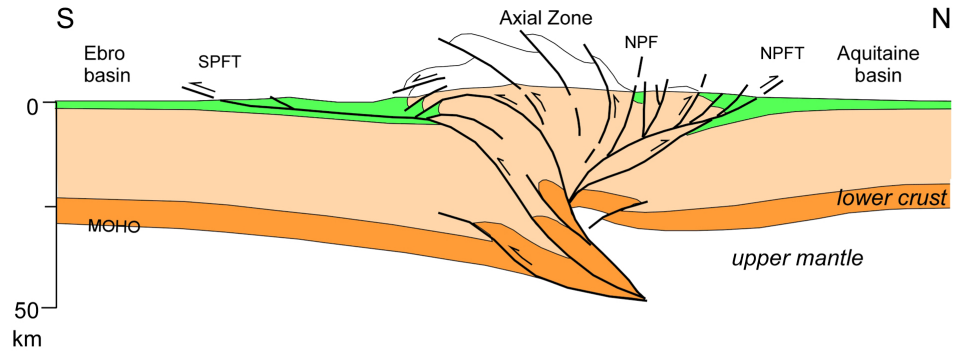

\section{B) ECORS-Pyrenees (Muñoz 1992)}

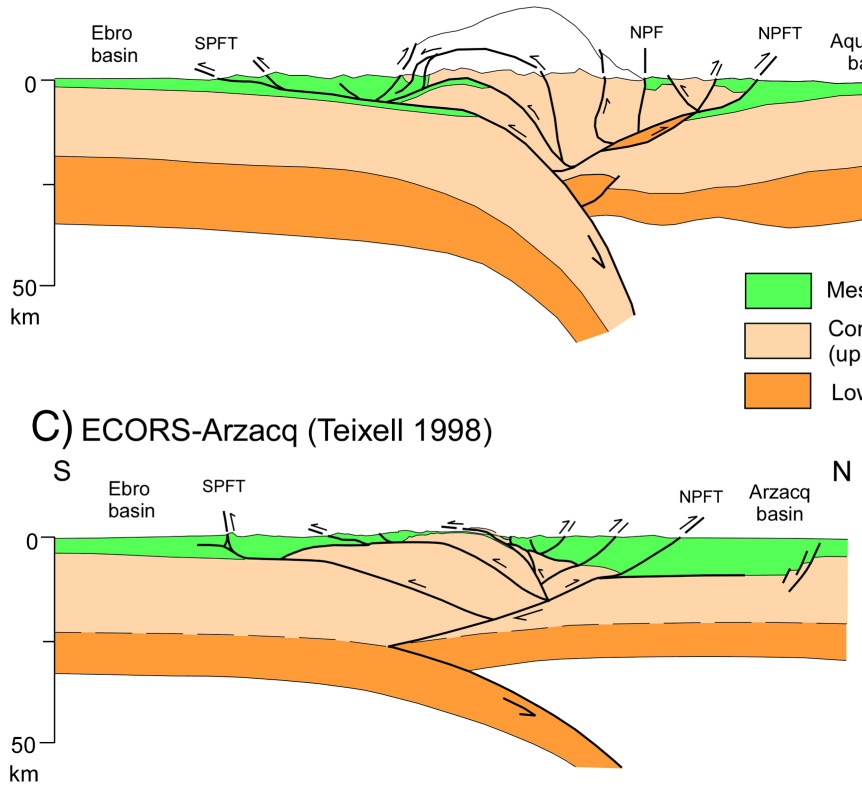

D) ESCIN 2 and 4 (Pulgar et al. 1996, Gallastegui 2000)

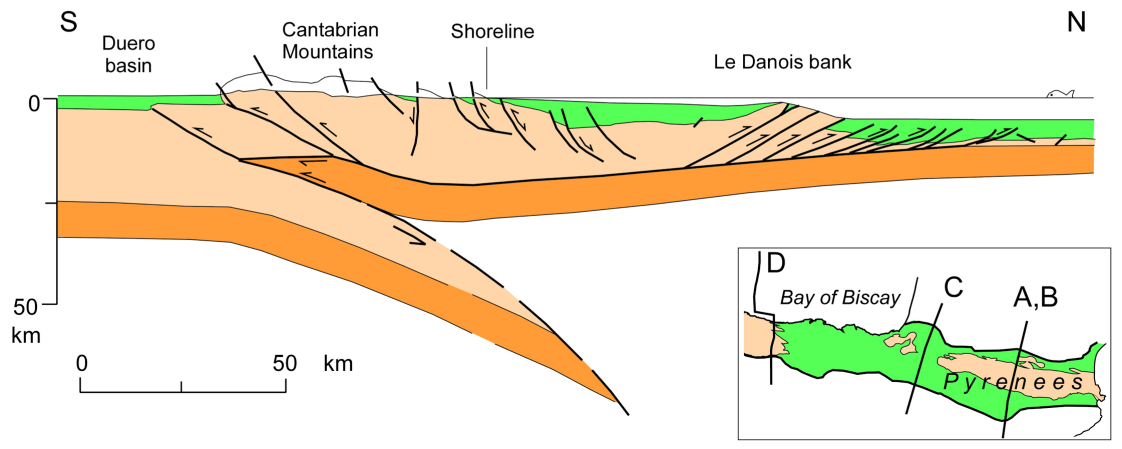


A) $\mathrm{s}$

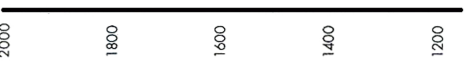

\begin{tabular}{lllll}
\hline 8 & 8 & 8 & 8 & 8
\end{tabular}
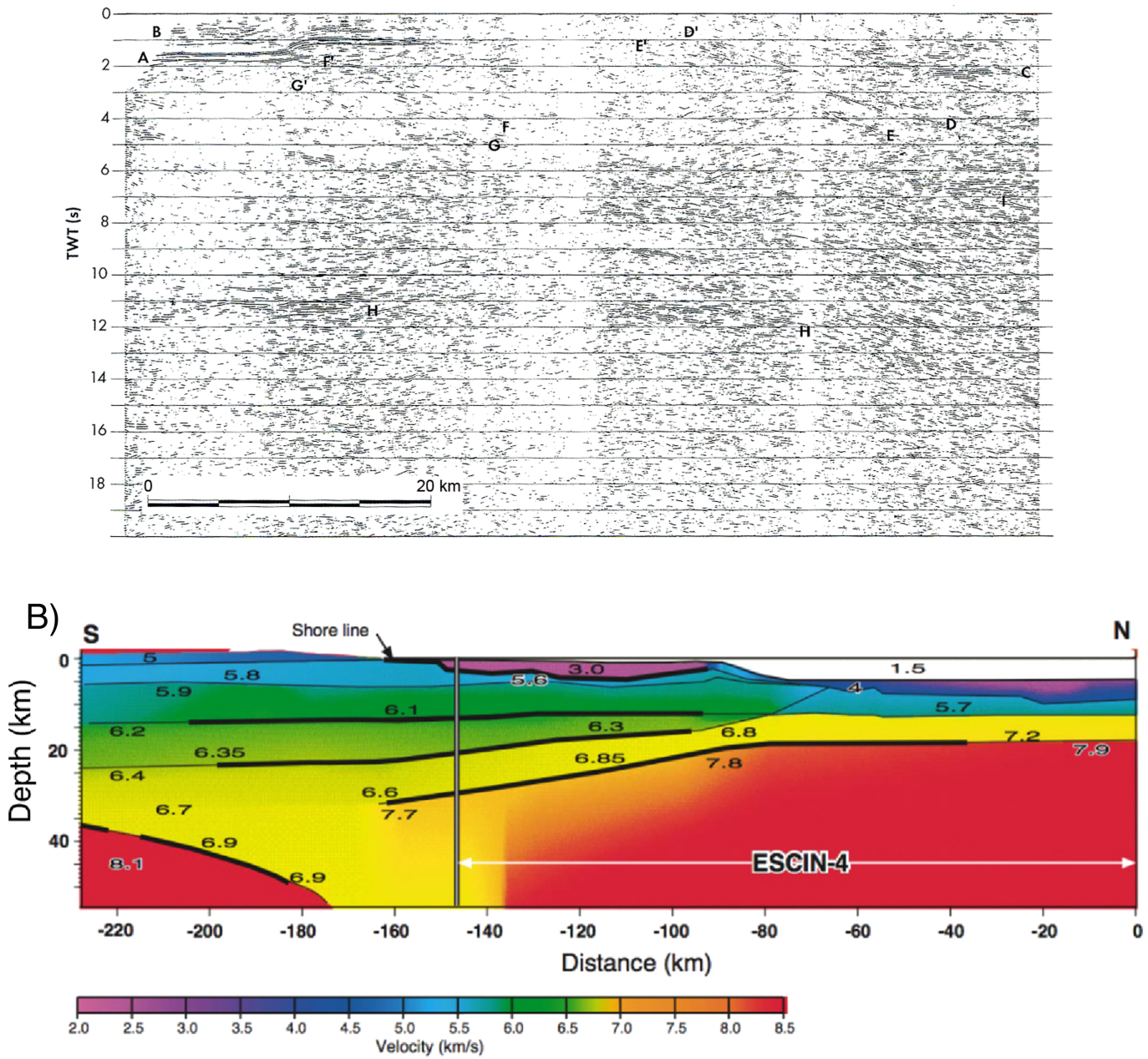


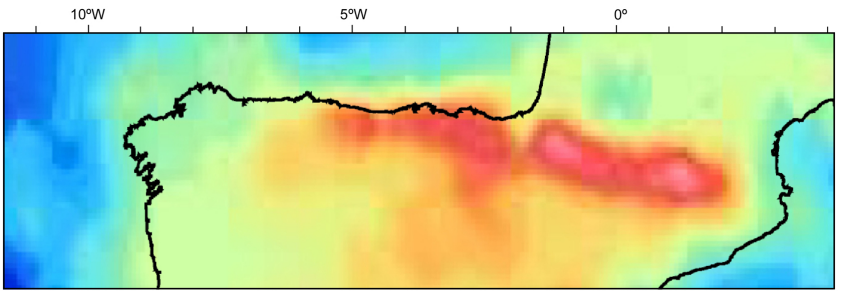

Moho depth (km)

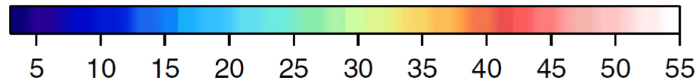

Figure 5 


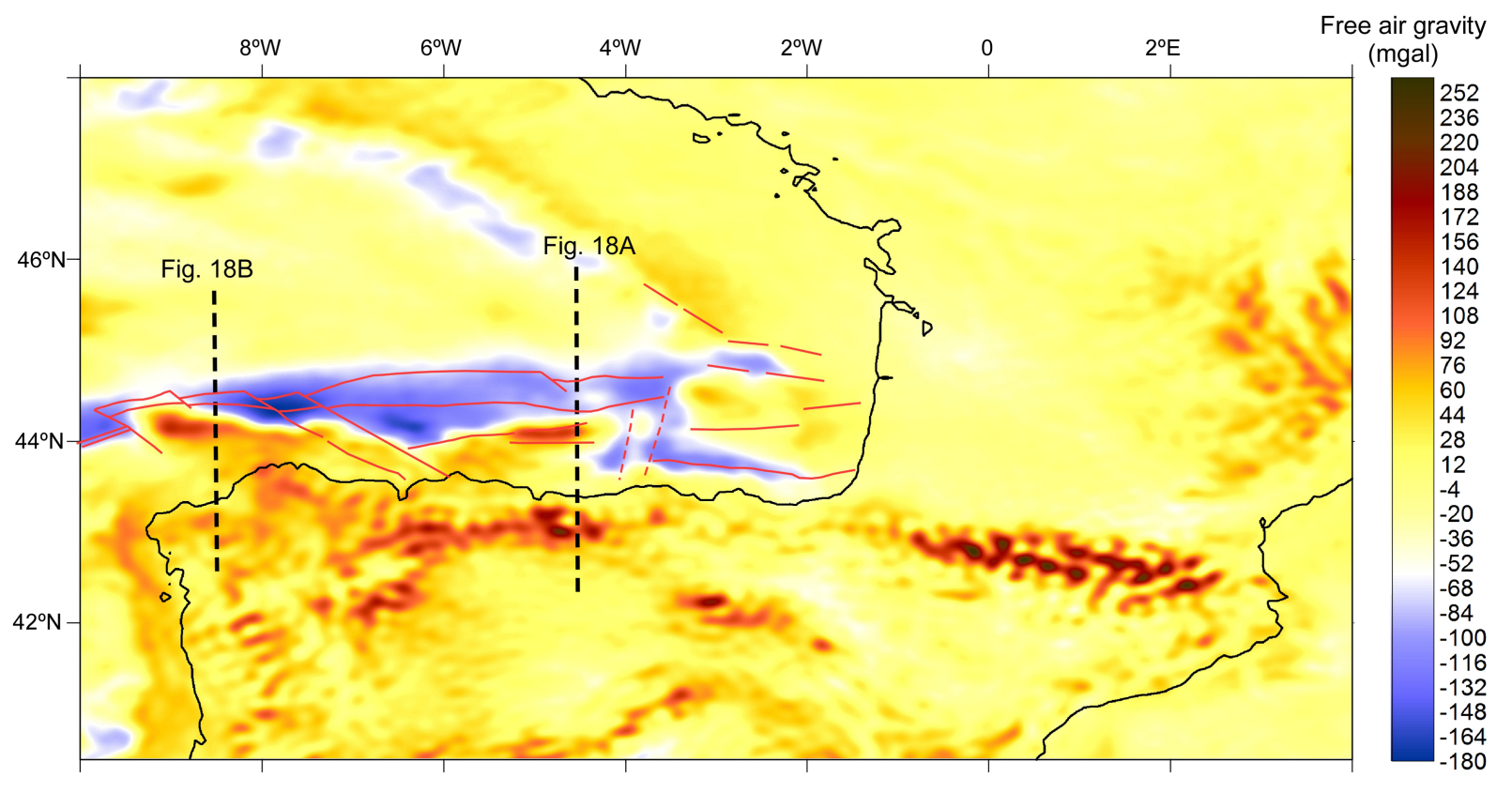

Figure 6 

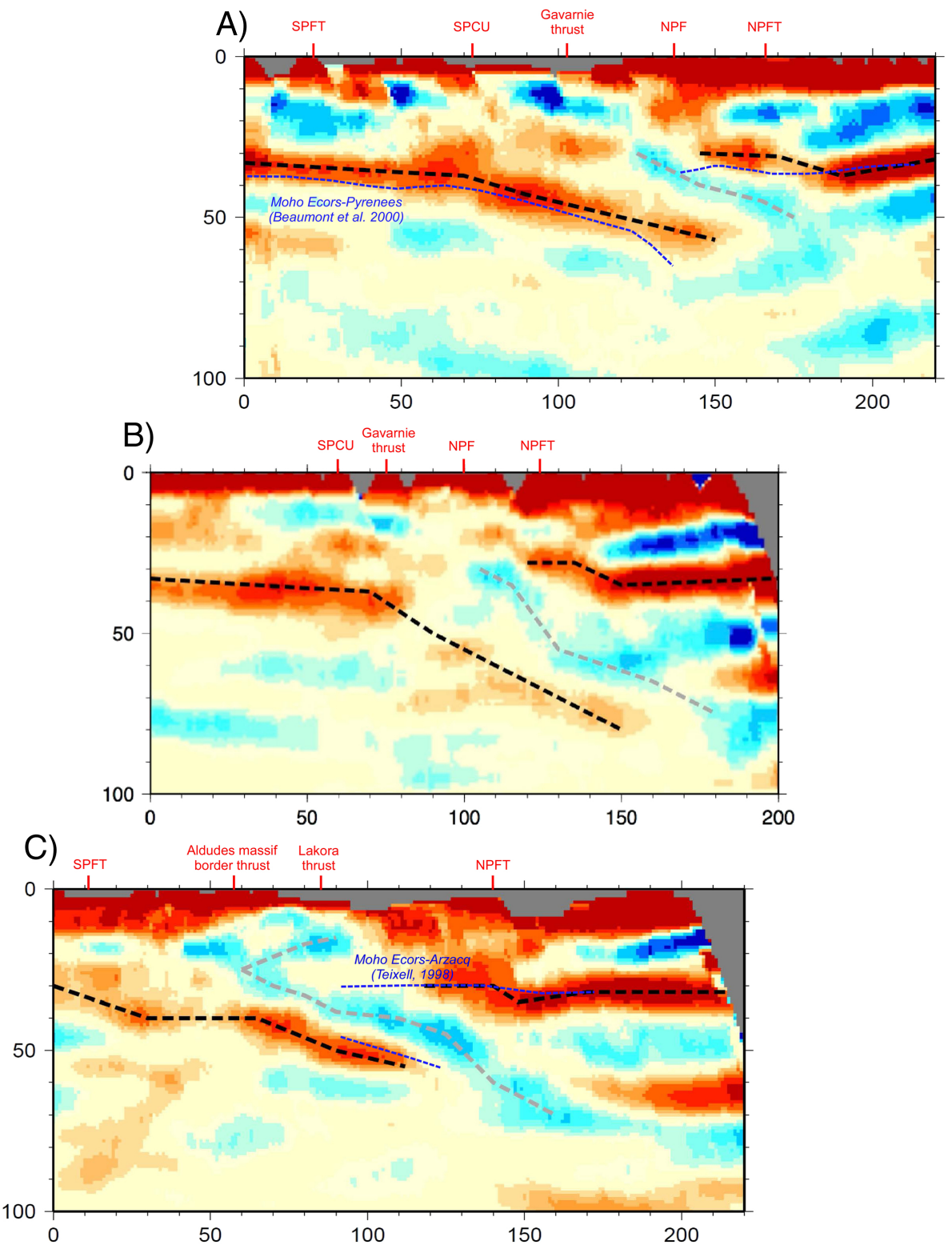

Figure 7 


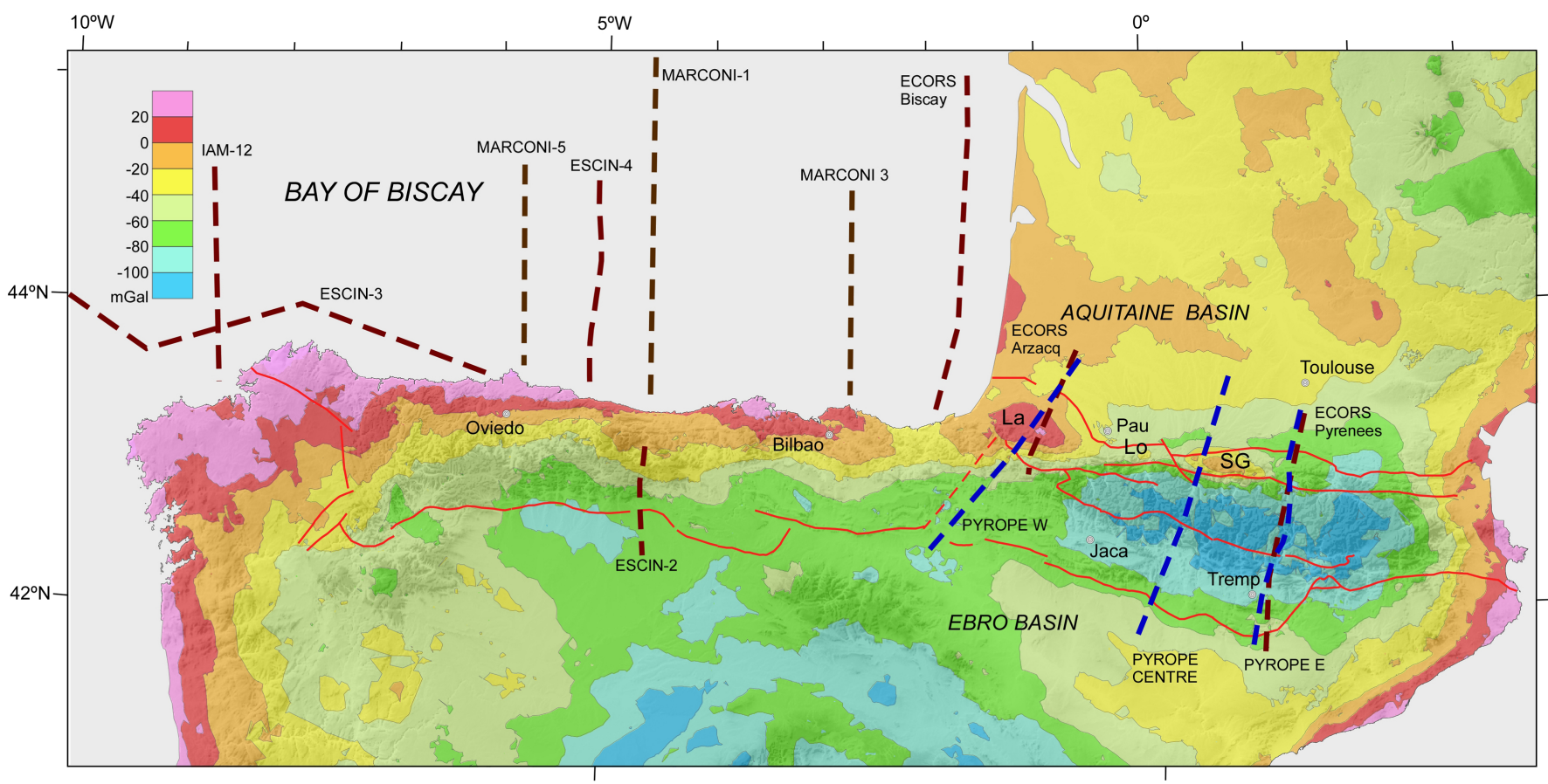

Figure 8 


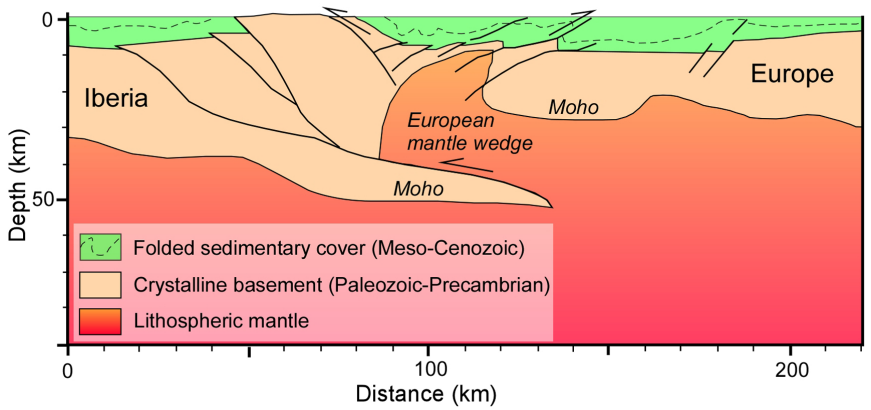

Figure 9 


\section{ECORS-Arzacq South (unmigrated)}

Arbailles

300
Col d'Osquiche

400

1
MAULÉON BASIN

500

0

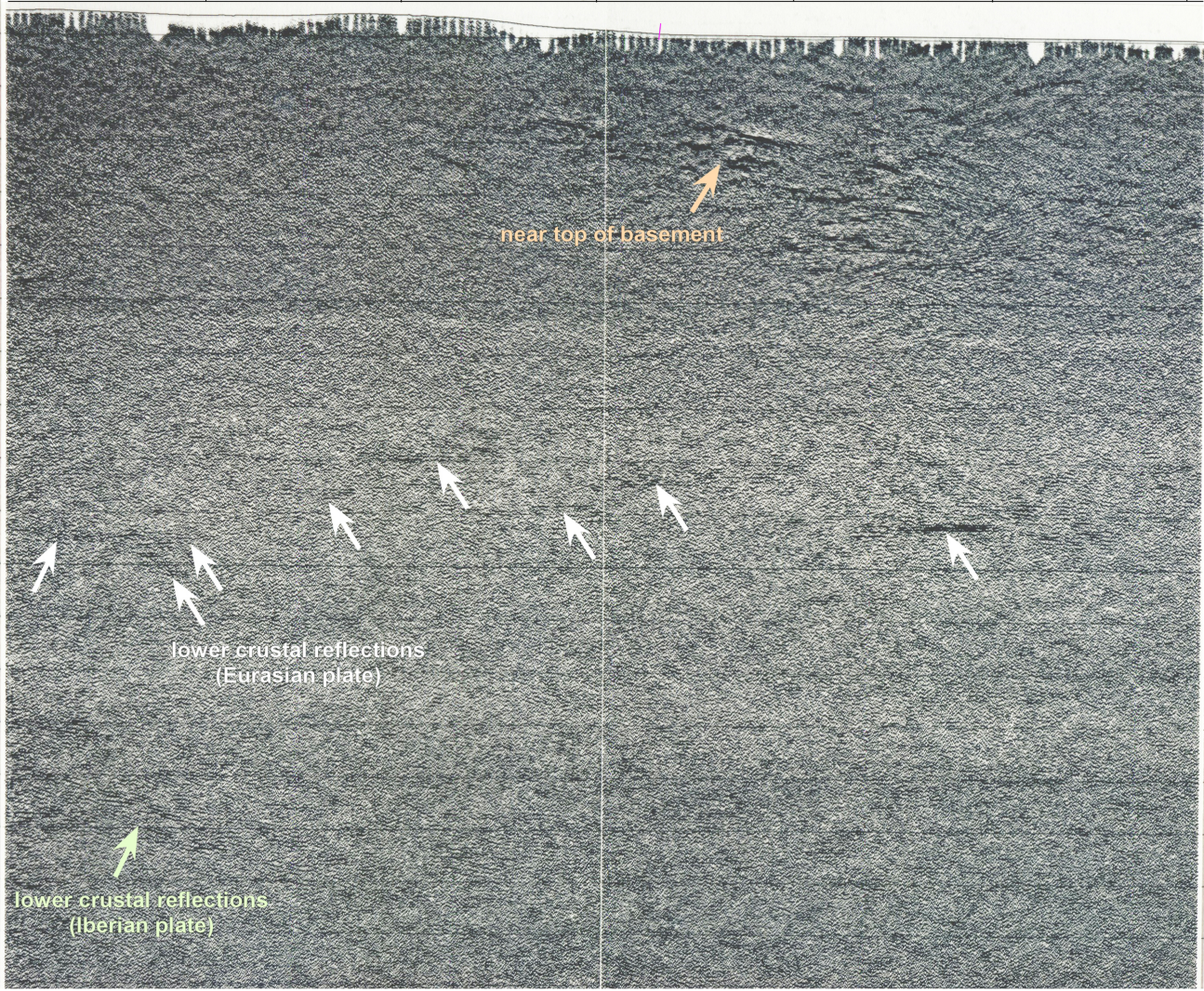




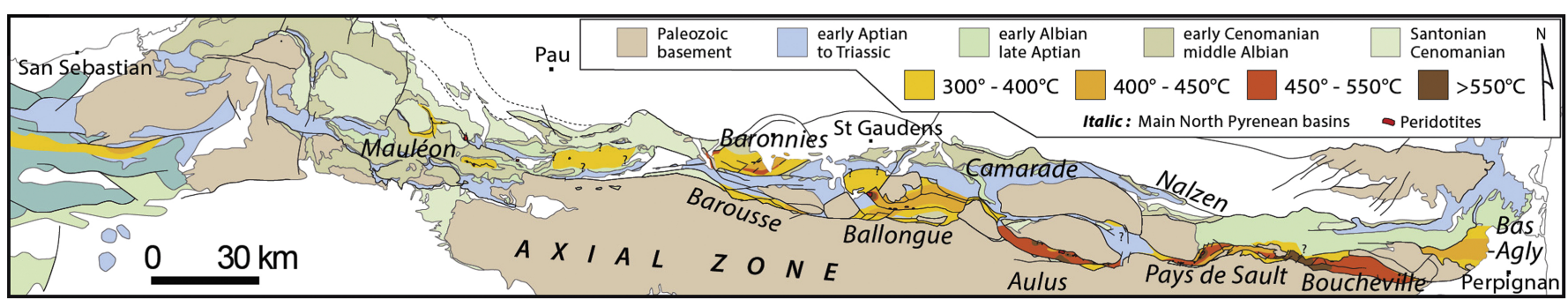

Figure 11 


\section{A)}

$\mathrm{s}$

South Mauléon

basin

North Mauléon

basin

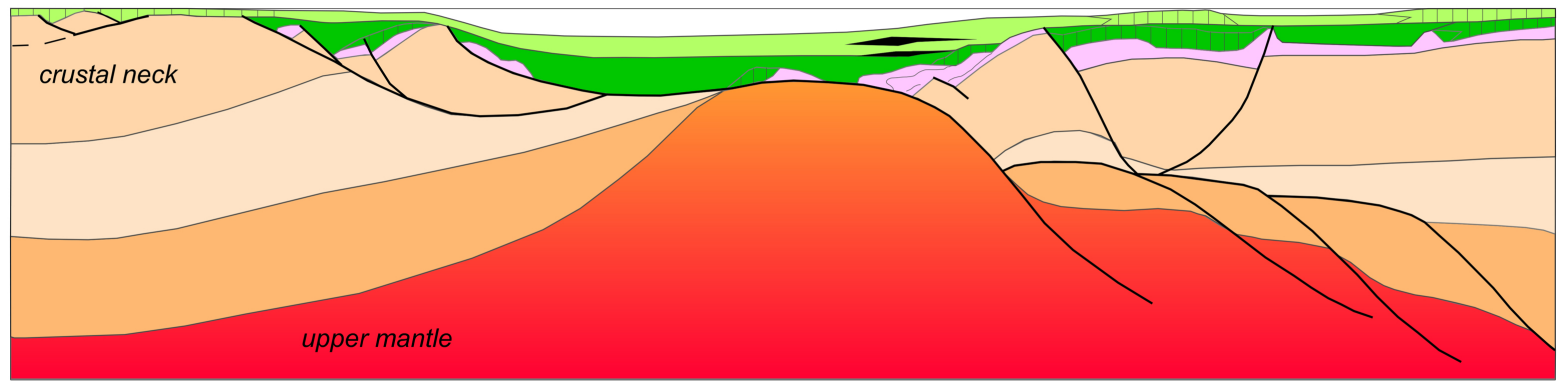

B)

$\mathrm{S}$

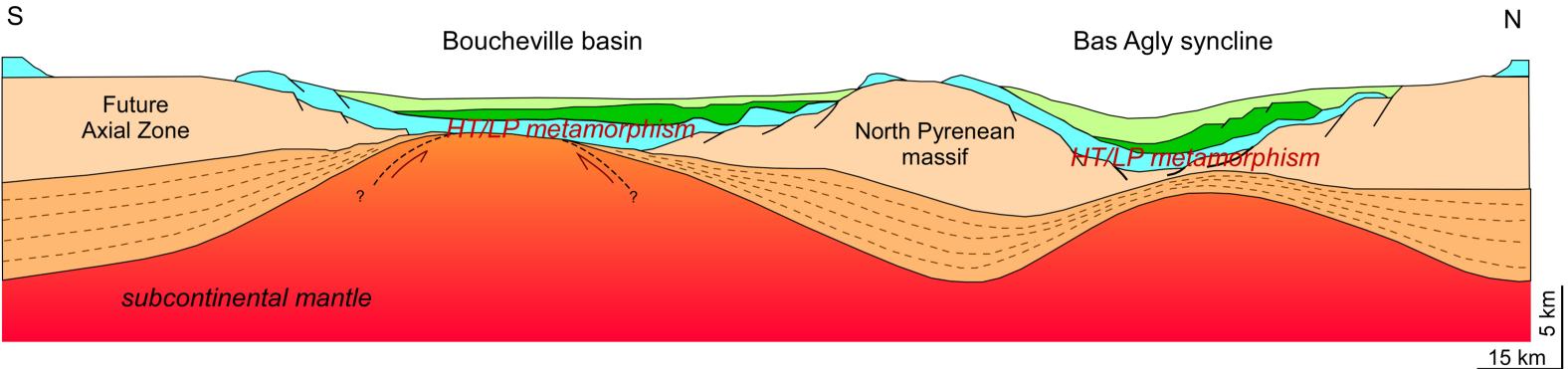

C)

$\mathrm{S}$

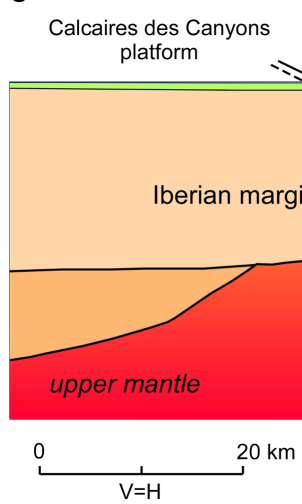

Chaînons Béarnais basin

Arzacq

Sarrance

Mail Arrouy basin Iherzolites

Iherzolites

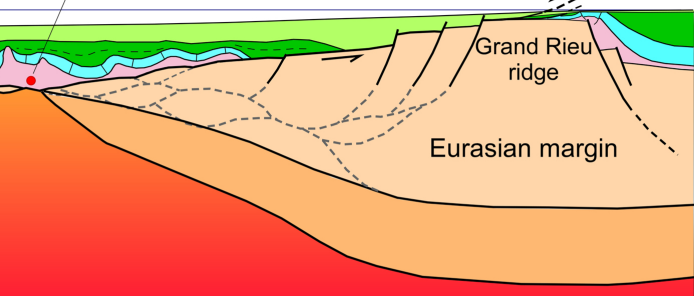

Eurasian margin

upper mantle

$\square$ Upper Cretaceous

Albian-Cenomanian

Jurassic to Aptian carbonates
Triassic Keuper

Continental basement + Lower-Middle Triassic (upper crust)

Lower crust

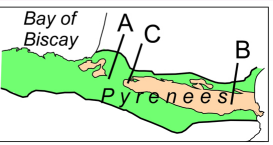

Figure 12 


\section{S}

Landes high Parentis basin

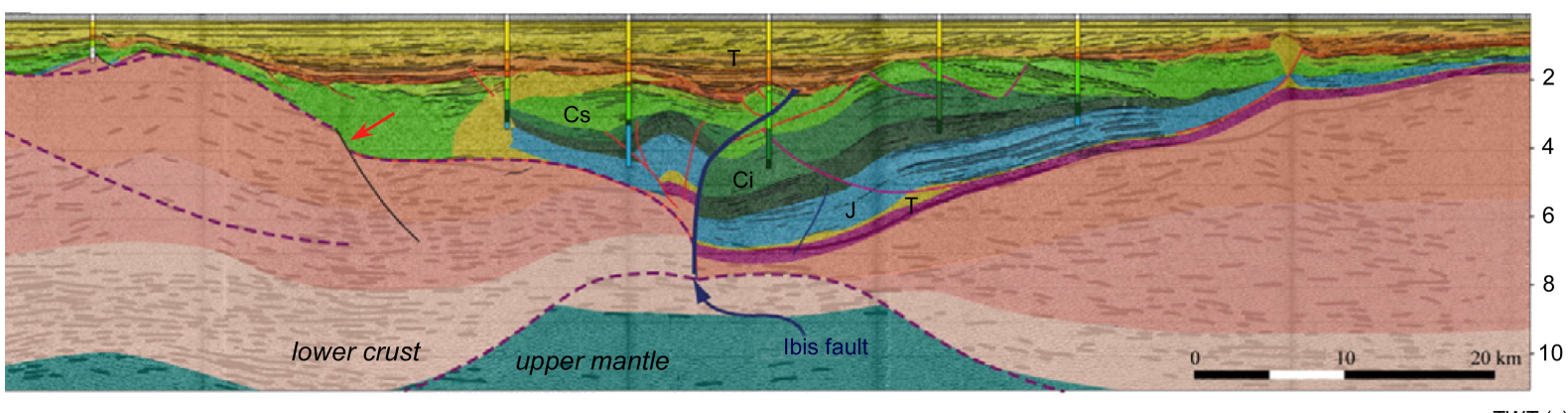

TWT (s)

Figure 13 


\section{S Proximal domain}

Continental slope

Absyssal plain

Asturian basin

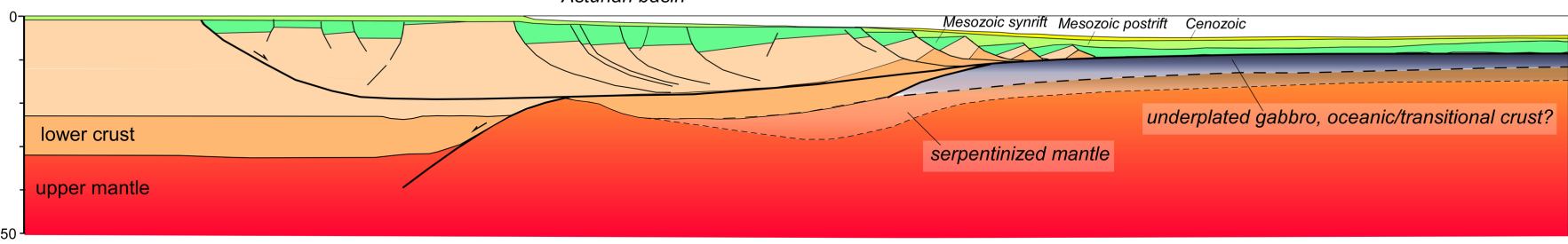

Figure 14 


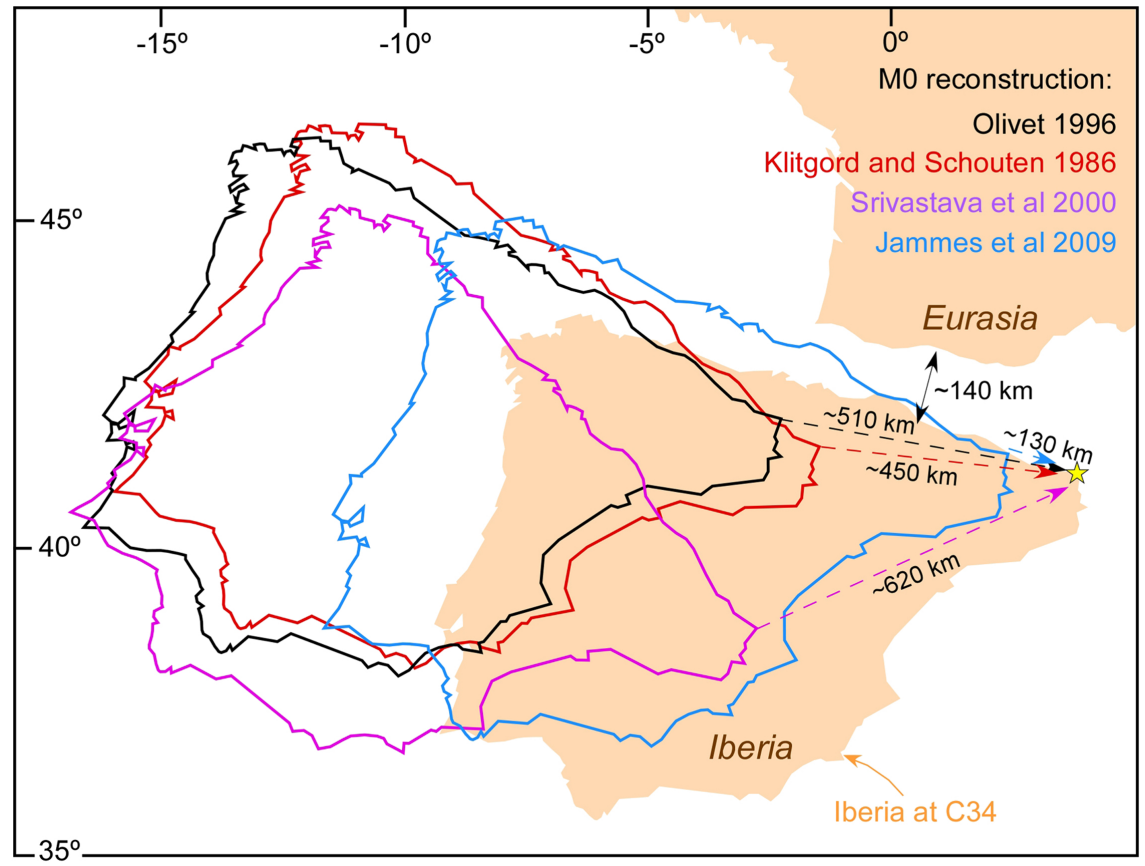

Figure 15 


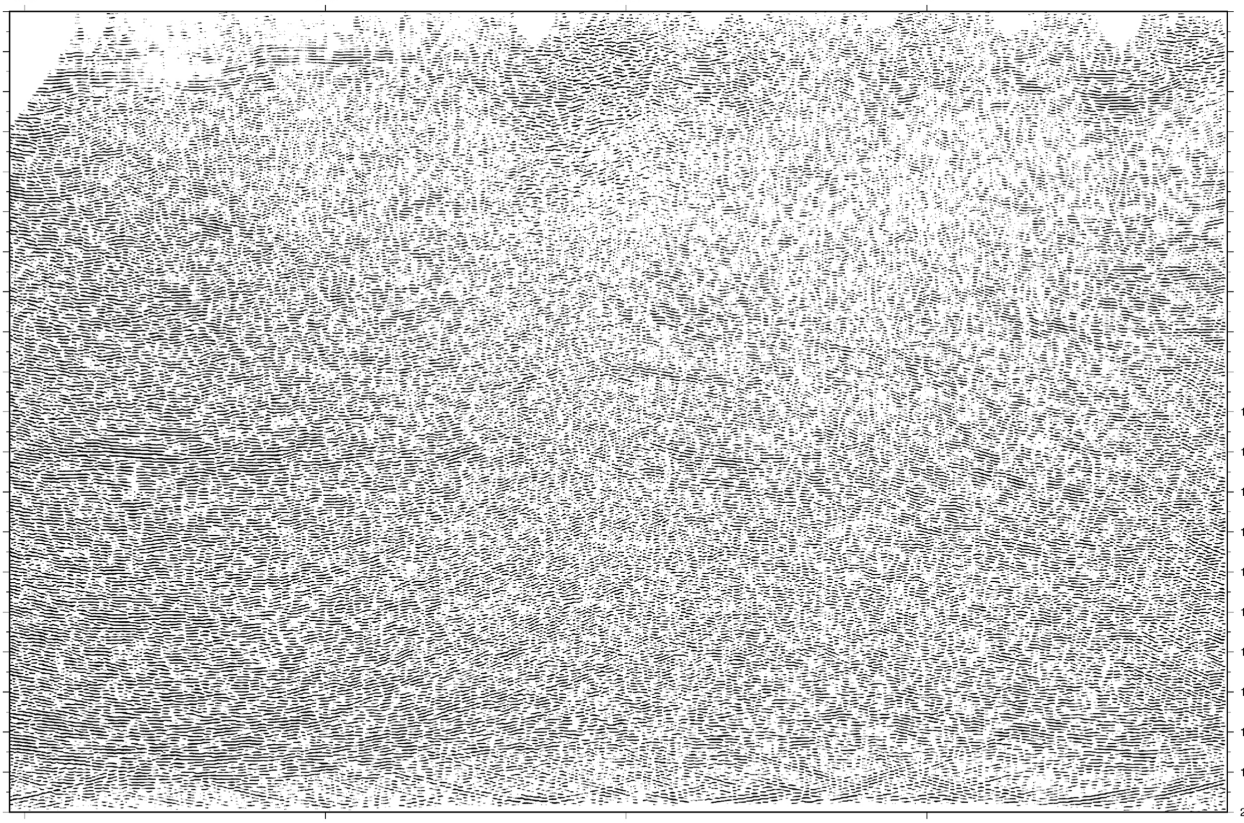

TWT

(s)

\section{CDP number}

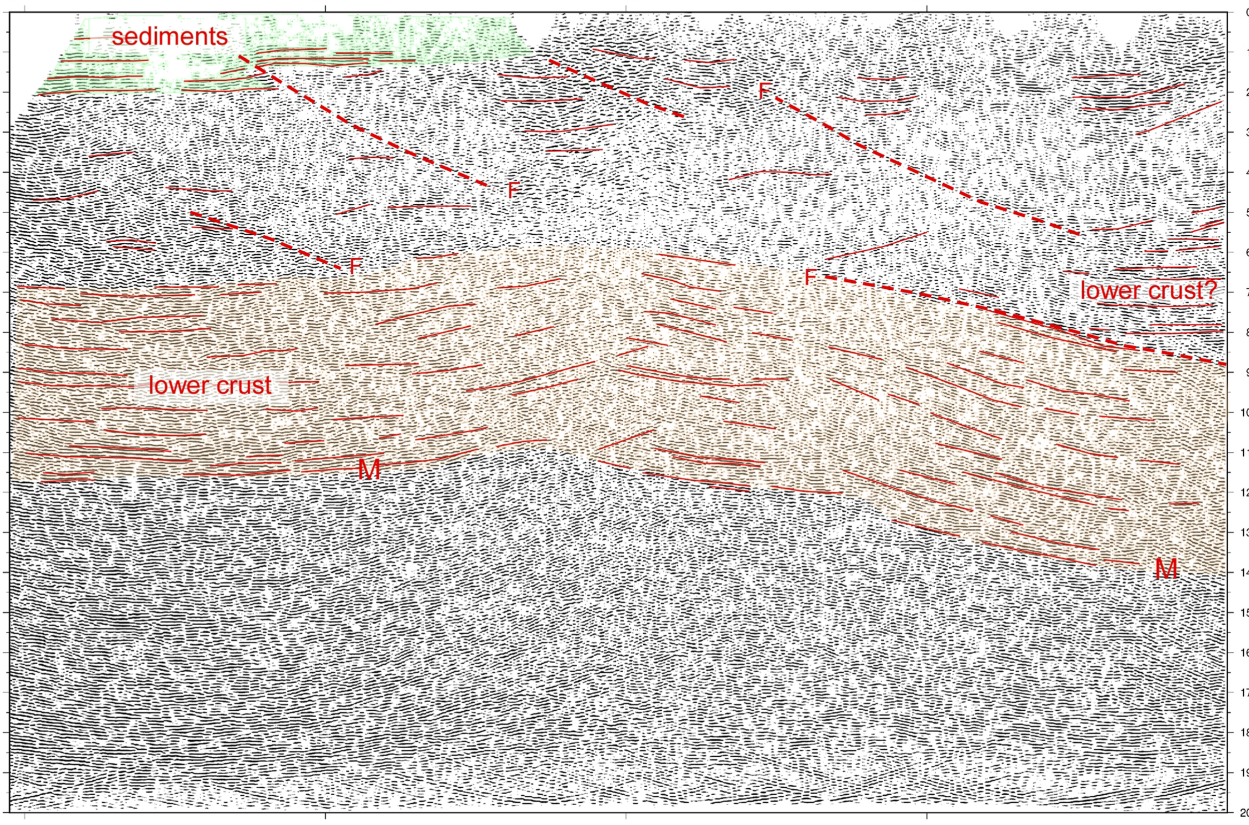




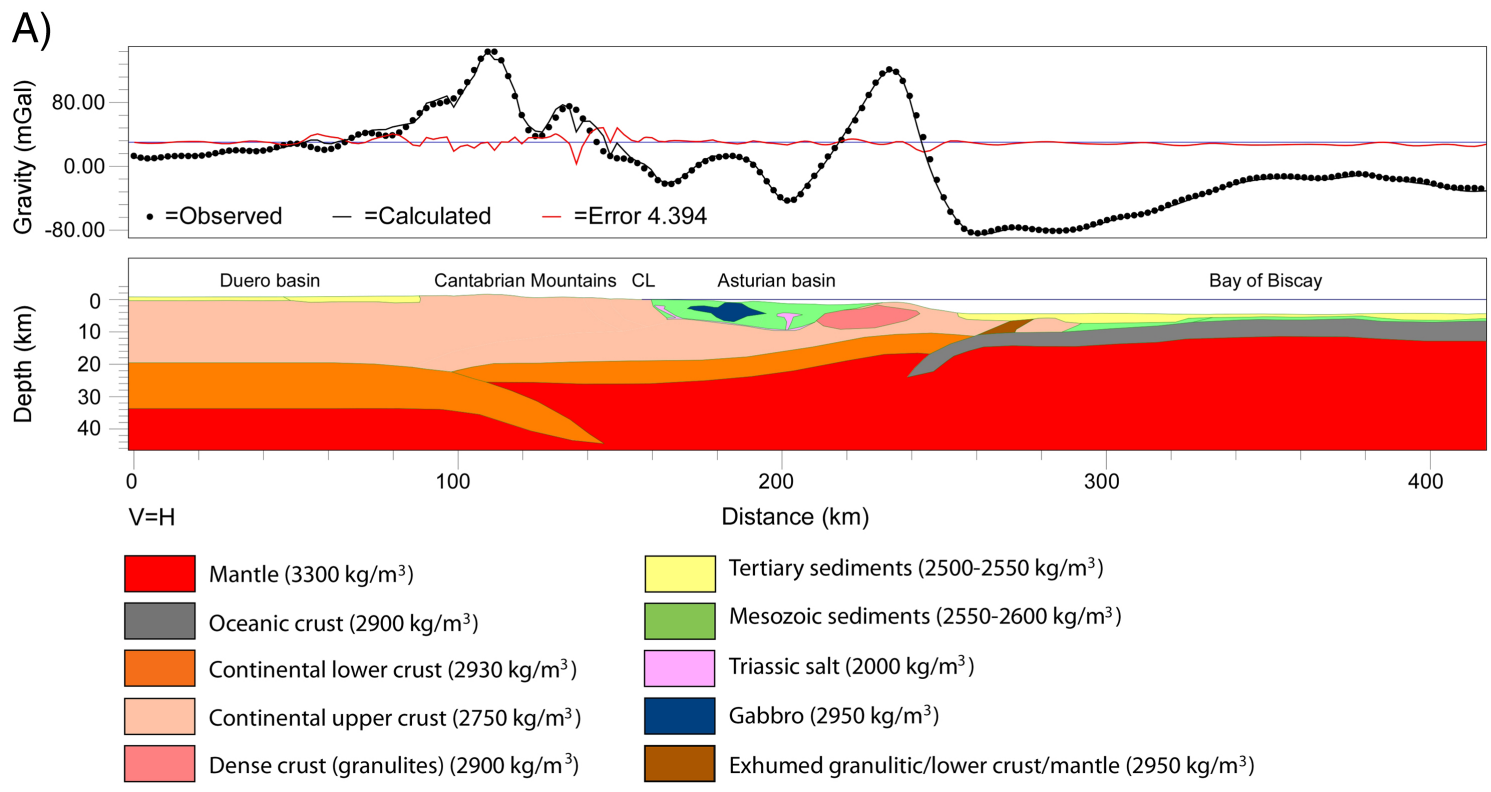

B)
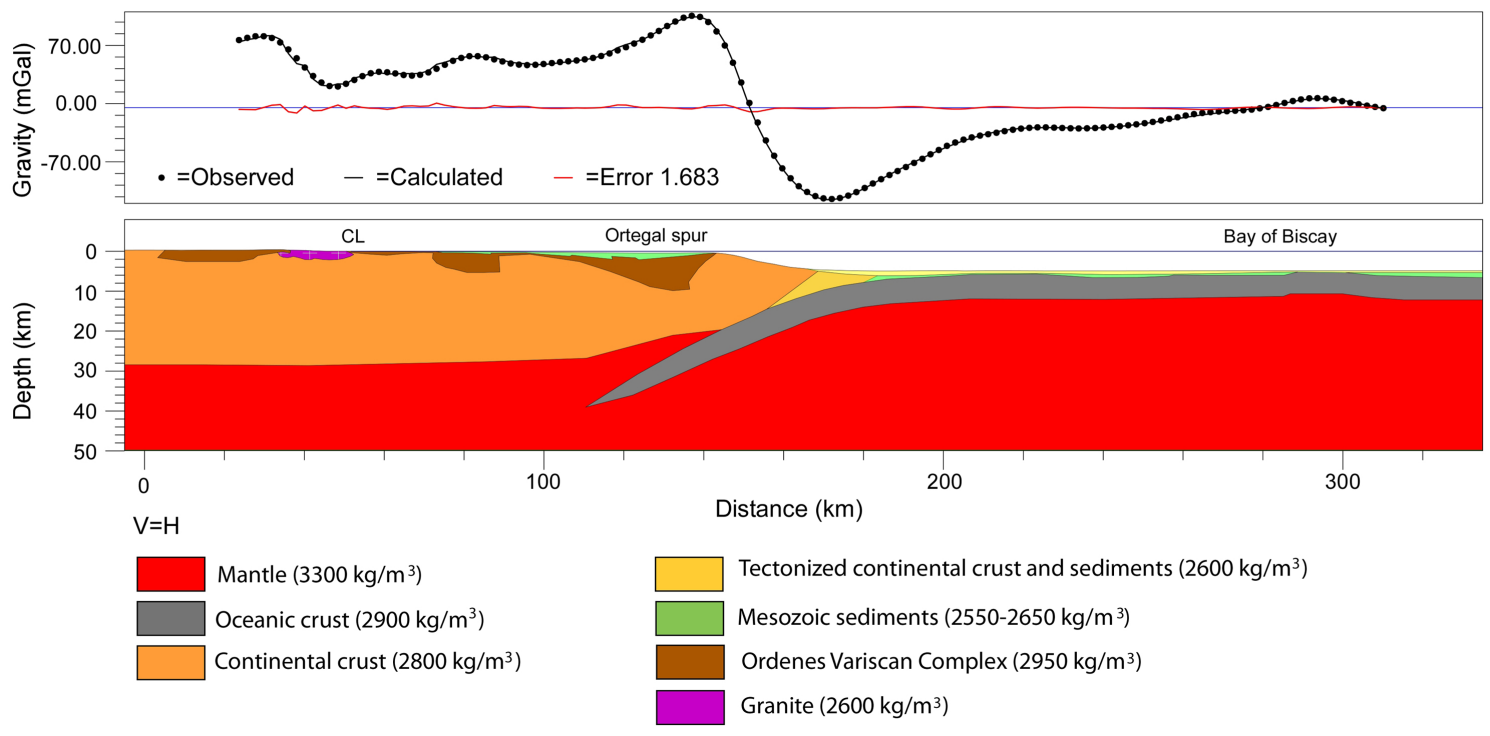

\section{Figure 19}


